\title{
NOTAS DE JURISPRUDENCIA
}

\section{Tribunal Constitucional (*)}

\begin{abstract}
SUMARIO: I. CONSTITUCIÓN. A. Fuerza normativa. B. Interpretación. II. DERECHOS Y LIBERTADES. A. Derechos fundamentales y libertades públicas. B. Derechos y deberes de los ciudadanos. C. Principios rectores de la política social y económica. D. Garantía y suspensión de estos derechos. III. PRINCIPIOS JURÍDICOS BÁSICOS. IV. INSTITUCIONES DEL ESTADO. A. La Corona. B. Las Cortes Generales. C. El Tribunal Constitucional. D. La Administración Pública. E. El Poder Judicial. V. FUENTES. VI. ORGANIZACIÓN TERRITORIAL DEL ESTADO. A. Comunidades Autónomas. A.1. Autonomía. B.2. Competencias. B. Corporaciones Locales. A.1. Autonomía B.2. Competencias. VII. ECONOMÍA Y HACIENDA. A. Principios generales. B. Presupuestos. C. Organización territorial. D. Tribunal de Cuentas.
\end{abstract}

\section{DERECHOS Y LIBERTADES}

\section{A. Derechos fundamentales y libertades públicas.}

1. Sentencia 156/2005, de 9 de junio (BOE de 8 de julio). Ponente: García-Calvo y Montiel (Cuestión de constitucionalidad).

Preceptos constitucionales: 24.1

otros:

Objeto: Párrafo primero del art. 136 del Código civil en relación con el art. 24.1 de la CE.

Materias: Tutela judicial efectiva: indefensión. Plazo preclusivo de ejercicio de una acción caducada sin que el agente haya podido conocer de los hechos que lo legitimarían para interponerla.

(*) Subsección preparada por FRANCISCO ESCRIBANO. 
Se planea cuestión de inconstitucionalidad respecto al párrafo primero del art. 136 del Código civil. Se duda si este precepto, en cuanto impide al marido impugnar su paternidad matrimonial una vez transcurrido un año desde la inscripción del nacimiento en el Registro Civil, incluso cuando las pruebas o indicios de que la paternidad no es cierta se hayan obtenido con posterioridad, es contrario al 24.1 CE. Se sustenta la duda de inconstitucionalidad en dos razones combinadas: de una parte, la brevedad del plazo que se le concede al marido para impugnar su paternidad matrimonial, que es de un año desde la inscripción del nacimiento o desde que tuvo conocimiento de él; de otra, que el precepto no tiene en cuenta para el cómputo del plazo de caducidad de la impugnación el hecho de que el padre contara o no con pruebas o indicios de que la paternidad no le correspondía. Al no otorgarle trascendencia al conocimiento de la posible falsedad biológica de la paternidad matrimonial el legislador habría introducido, según el cuestionante, un obstáculo desproporcionado al ejercicio legítimo de la acción de impugnación. La cuestión que se plantea es sustancialmente idéntica a la resuelta por el TC en su Sentencia 138/2005, pues tanto el objeto del proceso constitucional como el parámetro constitucional de control de este asunto coinciden con los que integran la decisión allí adoptada. En su FJ 4 puede leerse: el art. 136 CC cercena el acceso a la jurisdicción del padre que descubre no serlo una vez transcurrido un año desde la inscripción registral de la filiación, sin que esa limitación del derecho a la tutela judicial efectiva (art. 24.1 CE) guarde proporcionalidad con la finalidad perseguida de dotar de seguridad jurídica a la filiación matrimonial. La imposición al marido de una paternidad legal que, sobre no responder a la realidad biológica, no ha sido buscada (como ocurre en los casos de adopción y de inseminación artificial) ni consentida conscientemente, sino impuesta por una presunción legal (art. 116 CC), que siendo inicialmente iuris tantum (ATC 276/1996, de 2 de octubre, FJ 4) sin embargo, transcurrido un año desde la inscripción de la filiación, conocido el nacimiento, se transforma en presunción iuris et de iure, resulta incompatible con el mandato constitucional de posibilitar la investigación de la paternidad (art. 39.2 CE) y, por extensión, con la dignidad de la persona (art. 10.1 CE), asi como con el derecho a la tutela judicial efectiva (art. 24.1 CE) en su dimensión de acceso a la jurisdicción. Este será el sentir de esta decisión del TC, que trae aquí los argumentos ya expuestos en la señalada 138/2005. Allí ya se declaró la inconstitucionalidad del precepto cuestionado, mas, en todo caso teniendo en cuenta que esta inconstitucionalidad trae causa de que exige que el plazo para el ejercicio de la acción de impugnación de la paternidad matrimonial empiece a correr aunque el marido ignore no ser el progenitor biológico de quien ha sido inscrito como hijo suyo en el Registro Civil, y no de su duración, a la que se alude en el Auto de planteamiento de la presente cuestión. La inconstitucionalidad del precepto deriva (FJ 4 STC 138/2005) de lo que el precepto cuestionado tiene de norma excluyente. El enunciado legal, al referirse tan sólo al marido que desconoce el nacimiento del hijo, entraña la exclusión a contrario de quien, pese a conocer el hecho del nacimiento de quien ha sido inscrito como hijo suyo, sin embargo desconoce su falta de pater- 
nidad biológica, quedando de este modo al margen de la previsión legal. Pues bien, esa exclusión ex silentio tiene como consecuencia una imposibilidad real de ejercitar la acción impugnatoria por el marido que adquiere conocimiento de la realidad biológica una vez transcurrido un año desde que se hizo la inscripción registral. Se trata, por tanto, de una omisión del legislador que no puede ser resuelta mediante la anulación del precepto cuestionado sino con la actividad del legislador: La inconstitucionalidad apreciada exige que sea el legislador, dentro de la libertad de configuración de que goza, derivada de su posición constitucional y, en última instancia, de su específica legitimidad democrática (STC 55/1996, FJ 6), el que trace de forma precisa, en aras de la seguridad jurídica (art. 9.3 CE) el dies a quo del plazo para el ejercicio de la acción de impugnación de la paternidad matrimonial prevista en el art. 136 CC, dentro de cánones respetuosos con el derecho a la tutela judicial efectiva (art. 24.1 CE)" (STC 138/2005, FJ 6). En su FJ 6 es posible encontrar también la siguiente afirmación: no procede declarar la nulidad de la regla legal que concede hoy al marido la acción de impugnación de la paternidad legal, resultado éste que, sobre no reparar en nada la inconstitucionalidad apreciada, dañaria, sin razón alguna, a quienes ostentan, en virtud del art. 136 CC, una acción que no merece tacha alguna de inconstitucionalidad. La declaración de nulidad de este precepto, consecuente a la declaración de inconstitucionalidad, generaría un vacío normativo, sin duda no deseable. Teniendo en cuenta este extremo, no puede considerarse que la cuestión suscitada ahora haya perdido objeto. La pérdida de objeto en la cuestión de inconstitucionalidad implica la radical y absoluta imposibilidad de aplicación de la norma cuestionada, ocasionada por su derogación, modificación o expulsión del ordenamiento (STC 153/1986, FJ 2). Lo que no ocurre en este caso, ya que no se ha efectuado un pronunciamiento de nulidad del precepto cuestionado. En atención a esta consideración, estima el TC que la remisión al meritado Fallo, deba hacerse ahora en los siguientes términos: declarar inconstitucional el párrafo primero del art. 136 del Código civil, en la redacción dada por la Ley 11/1981, de 13 de mayo, en cuanto comporta que el plazo para el ejercicio de la acción de impugnación de la paternidad matrimonial empiece a correr aunque el marido ignore no ser el progenitor biológico de quien ha sido inscrito como hijo suyo en el Registro Civil. Procede estimar la presente cuestión de inconstitucionalidad.

Voto particular (Jiménez Sánchez y Delgado Barrio): Por coherencia, en la medida en que esta STC se remite en su argumentación y Fallo a la $138 / 2005$, se remiten también los disidentes a los argumentos que allí quedaron expuestos.

(Gay Montalvo): Se hace remisión al VP que ya se hizo en relación con la STC 138/2005, y en el que, básicamente, se afirmaba que debía haberse desestimado la cuestión planteada por ser el art. 136 del Código civil conforme con la Constitución.

\section{Sentencia 190/2005, de 7 de julio (BOE de 5 de agosto). Ponente: Delgado Barrio (Cuestión de constitucionalidad).}


Preceptos constitucionales: 9.3; 14; 24.1; 117.3.

otros:

Objeto: Art. 1.2 de la Ley sobre responsabilidad civil y seguro en la circulación de vehículos a motor, en la redacción dada por la disposición adicional octava de la Ley 30/1995, de 8 de noviembre, de ordenación y supervisión de los seguros privados, en relación con los puntos 1 y 4 del apartado primero del anexo y su tabla I.

Materias: Derecho a la igualdad. Tutela judicial efectiva.

Como ya puso de manifiesto el TC, en su Sentencia 181/2000 el legislador dispone de plena legitimidad constitucional para regular el sistema indemnizatorio con la densidad normativa que estime oportuno en lo que atañe a la valoración y cuantificación de los daños personales habida cuenta de la libertad de configuración de que dispone (FJ 19), siendo de añadir que tal sistema se traza después de una larga experiencia en esta materia, adquirida, sobre todo, después de la introducción del baremo orientativo de la Orden Ministerial de 5 de marzo de 1991 con los magros resultados obtenidos respecto de los perfectamente legítimos objetivos que perseguía, objetivos que resultan enteramente predicables del sistema de baremo vinculante aprobado por la Ley 30/1995 y que conviene no perder de vista cuando de esta cuestión se trata: la consecución de un sistema dotado de mayores niveles de certeza y seguridad jurídica ... fomentar un trato análogo en situaciones semejantes de responsabilidad, servir de marco e impulso para alcanzar acuerdos transaccionales, agilizar al máximo el pago por siniestros de esta indole, reducir la litigiosidad y permitir a las entidades aseguradoras establecer previsiones fundadas (FJ 13). En definitiva, como ya se señaló en la citada STC 181/2000, FJ 13, el punto de partida ha de ser que no cabe aceptar que la opción del legislador a favor de un sistema legal de valoración tasada de los daños corporales regulado en la Ley 30/1995 sea arbitrario, contraviniendo lo dispuesto en el art. 9.3 de la Constitución. Existen poderosas razones para justificar objetivamente un régimen jurídico específico y diferenciado en relación con los daños producidos como consecuencia de la circulación de vehículos a motor. Así, la alta siniestralidad, la naturaleza de los daños ocasionados y su relativa homogeneidad, el aseguramiento obligatorio del riesgo, la creación de fondos de garantía supervisados por la Administración (Consorcio de Compensación de Seguros) y, en fin, la tendencia a la unidad normativa de los distintos ordenamientos de los Estados miembros de la Unión Europea, son factores concurrentes perfectamente susceptibles de ser valorados por el legislador y que justifican suficientemente y hacen plausible la opción legislativa finalmente acogida, en cuanto sistema global. El Auto de planteamiento de la cuestión argumenta la duda que suscitan al órgano judicial los ya indicados preceptos desde la perspectiva del derecho a la igualdad en la ley (art. 14 CE) destacando, por una parte, que la finalidad de la norma que tiene que apli- 
car, contenida en la tabla I (grupo IV) del anexo citado, es primordialmente la de la reparación de los daños morales (pues al tratarse de hermanos de la víctima, no serán razones de dependencia o apoyo económico las relevantes, salvo excepciones) derivados del grado o intensidad de la aflicción por la pérdida de un familiar próximo. Por otra parte, pone el acento el citado Auto en la supuestamente arbitraria selección de quién haya de estimarse perjudicado que provocaría una discriminación prohibida por razón de la edad, ya que, en el contexto mencionado, la diferenciación entre los hermanos mayores y menores de edad carecería de relación alguna con el sentido de la regulación. Del mencionado planteamiento se deduce con claridad que la alusión al principio de interdicción de la arbitrariedad del legislador (art. 9.3 CE) la subsume el órgano judicial en la duda, más perfilada, que se articula con apoyo en el art. 14 CE. Como destacó la STC 244/2000, FJ 1, la duda de constitucionalidad suscitada, desde la perspectiva del art. $14 \mathrm{CE}$, en relación con la exclusión de ciertos grupos de familiares del elenco de beneficiarios posibles de las indemnizaciones fijadas mediante baremación en la Ley 30/1995 no ha sido objeto de consideración por nuestra STC 181/2000, de 29 de junio. Por consiguiente, la doctrina sentada en la misma resulta sólo de indirecta aplicación a un caso como el presente. La mencionada STC 181/2000 (FFJJ 10 y 11) analizó si era conforme con el art. $14 \mathrm{CE}$ la diferencia de regímenes de responsabilidad que resultaba del dato objetivo referido a que los daños se hubiesen o no producido en el ámbito de la circulación de vehículos a motor, pero no se contrastó con el citado precepto constitucional ninguna regulación especial o diferencia articulada a partir de categorías de personas o grupos de las mismas. En el caso presente, lo que se somete a la consideración del TC sí es una diferencia de trato entre personas, en concreto, entre los hermanos mayores de edad y los menores que hubieran convivido con la víctima: a los primeros no atribuye la Ley la condición de perjudicados-beneficiarios, a los segundos sí. Ya se traía a colación en la STC 181/2000, FJ 10, la doctrina de este Tribunal sobre el derecho a la igualdad en la ley (art. $14 \mathrm{CE}$ ), que puede considerarse resumida en el FJ 1 de la STC 144/1988, de 12 de julio, en el que se declaró que el principio de igualdad prohíbe al legislador 'configurar los supuestos de hecho de la norma de modo tal que se dé trato distinto a personas que, desde todos los puntos de vista legítimamente adoptables, se encuentran en la misma situación o, dicho de otro modo, impidiendo que se otorgue relevancia jurídica a circunstancias que, o bien no pueden ser jamás tomadas en consideración por prohibirlo asi expresamente la propia Constitución, o bien no guardan relación alguna con el sentido de la regulación que, al incluirlas, incurre en arbitrariedad y es por eso discriminatoria'. Para llevar a cabo esa labor fiscalizadora de la ley desde la indicada perspectiva del derecho de igualdad, este Tribunal ha recurrido en ocasiones a cánones complementarios de enjuiciamiento, como lo es el de exigir que exista una justificación objetiva y razonable de la diferencia (SSTC 75/1983, de 3 de agosto, 150/1991, de 4 de julio, y 222/1992, de 11 de diciembre, entre otras muchas), y a pautas de general aplicación al legislador de los derechos fundamentales, como las que se derivan del principio de proporcionalidad y, más in extenso, de la necesaria adecuación entre las medidas adoptadas y los fines per- 
seguidos. Para proceder a la aplicación de esta doctrina al caso de autos se ha de subrayar que las ya aludidas limitaciones cuantitativas de las indemnizaciones corren paralelamente a la determinación de la lista de perjudicadosbeneficiarios: así, el grupo IV incluye en aquélla los hermanos menores de edad con exclusión de los mayores. Junto a esto, se ha de indicar que la propia tabla I contempla como perjudicados-beneficiarios a los hermanos mayores de edad de la víctima mortal en accidente de circulación en el siguiente grupo de la misma, el V y último, bajo la rúbrica Víctima con hermanos solamente. Lo que evidencia que el legislador no niega el carácter de perjudicados morales a los hermanos mayores de edad de la víctima fallecida en el siniestro circulatorio, sino que caso de que pervivan a la misma sus ascendientes, opta (grupo IV) por concentrar las cantidades resarcitorias en éstos y en los hermanos menores de edad. La ausencia de los hermanos mayores de edad en las previsiones del grupo IV no se debe a ningún propósito del legislador de excluirlos de la condición de perjudicados-beneficiarios, sino a la concreta circunstancia que se describe en la rúbrica de dicho grupo, es decir, a la existencia de ascendientes y eventualmente de hermanos menores de la víctima del accidente de tráfico cuando ésta carece de cónyuge e hijos atendiendo a la ratio limitadora de las compensaciones económicas que preside el sistema, y es que la concurrencia con unas u otras personas puede dar lugar a supuestos indemnizatorios diferenciados, dado que la limitación de las cantidades resarcitorias por víctima mortal en accidente de circulación constituye manifiestamente uno de los pilares del sistema regulado por la Ley sobre responsabilidad civil de vehiculos a motor (STC 105/2004, FJ 7). Es indudable que perfectamente podría haber optado el legislador por añadir a los familiares previstos en el grupo IV a los hermanos mayores de edad de la víctima fallecida, ya incluyéndolos también como otros perjudicados-beneficiarios más con sus propias cantidades a percibir, ya prorrateando una cantidad global en función de los ascendientes y del resto de hermanos, ya con cualquier otra fórmula. No lo ha hecho así, prefiriendo concentrar en los ascendientes y en los hermanos menores de edad, las cantidades resarcitorias $\mathrm{y}$, a la vista de tal solución, parece difícil que pueda tildarse de caprichoso o arbitrario el criterio utilizado para anudar a esas desiguales situaciones el efecto limitativo de cuya constitucionalidad se duda (STC 100/1990, FJ 5), cuando tal criterio resulta consistir en un dato tan objetivo como la mayoría de edad, que obviamente comporta para quienes no llegan a ella una situación socio-jurídica sensiblemente distinta de quienes la rebasan, convirtiendo a unos y otros en términos que no admiten adecuada comparación. En relación con la minoría de edad, convendrá tener presente que Dado que para el examen de la constitucionalidad de una ley la interpretación de ésta es un prius lógico insoslayable (STC 83/2005, FJ 3) es necesario llamar la atención sobre una finalidad de los preceptos cuestionados no destacada por la interpretación realizada por el Auto de planteamiento de la cuestión. Según éste, el único dato considerado relevante por aquéllos para atribuir al hermano de la víctima la consideración de perjudicado-beneficiario sería la intensidad de la relación 
afectiva que derivaría de los elementos típicos de esa relación de parentesco y de la convivencia. De la regulación cuestionada se desprende, fácilmente, sin embargo, que a la finalidad de la misma de reparar predominantemente un daño afectivo se añade otra que es la de prestar la protección derivada del derecho a recibir indemnización a una categoría de personas también típicamente necesitada de una mayor protección: la de los menores de edad (art. 39.3 y $4 \mathrm{CE}$ ). No será irrelevante destacar, a estos efectos, que varios de los preceptos del capítulo tercero del título primero de la Constitución tienen como función la de identificar grupos de personas necesitados de especial protección [menores y madres (art. $39 \mathrm{CE}$ ), minusválidos (art. $49 \mathrm{CE}$ ), ancianos (art. 50), etc.]. Desde la perspectiva del principio de igualdad, esas referencias constitucionales específicas a colectivos personales permiten el establecimiento de tratos diferenciadores positivos o favorables que, aunque impliquen una desigualdad, no pueden considerarse contrarios al art. $14 \mathrm{CE}$. El TC ha hecho uso de los mencionados principios rectores que identifican grupos personales merecedores de especial protección: la maternidad y, por tanto, el embarazo y el parto son una realidad biológica diferencial objeto de protección, derivada directamente del art. 39.2 CE y, por tanto, las ventajas o excepciones que determine para la mujer no pueden considerarse discriminatorias para el hombre (STC 109/1993, FJ 4); no es contrario al art. $14 \mathrm{CE}$ ni al art. 23.2 CE una reserva porcentual de plazas para minusválidos en una oferta de empleo público en atención al mandato de protección de los discapacitados que se contiene en el art. 49 CE (STC 269/1994, de 3 de octubre, FJ 4) y un largo etc. La diferenciación mayoría-minoría de edad es constitucionalmente legítima, dando lugar a status jurídicos distintos, que determinan una mayor protección de los menores, como la propia Constitución también reconoce -arts. 39.3 y 4 CE-. Estas previsiones constitucionales poseen virtualidad bastante para generar un trato favorable. No podrá considerarse contrario a las exigencias de igualdad que los hermanos menores de edad de la víctima gocen de una protección (la derivada del reconocimiento de la condición de perjudicado-beneficiario) que no se dispensa a los mayores de edad. Procede ahora el TC a examinar la conexión del derecho a la tutela judicial efectiva -art. 24.1 CE- y la reserva jurisdiccional -art. 117.3 CE-. Lo que el órgano judicial entiende que podría vulnerar el derecho a la tutela judicial efectiva garantizado en el art. 24.1 CE, es que la regulación cuestionada disponga un elenco cerrado de los posibles perjudicados por el fallecimiento de una víctima en accidente circulación, de modo que no quepa admitir que ningún otro individuo por más que efectivamente haya sufrido un daño moral por tal fallecimiento, pueda tener la consideración de perjudicado a los efectos de la Ley sobre responsabilidad civil y seguro en la circulación de vehículos a motor: el establecimiento de un sistema cerrado y exhaustivo de enumeración pormenorizada de perjudicados en las tablas correspondientes, es incompatible con los postulados del art. $24.1 \mathrm{CE}$, pues se traduce en la definitiva e irremediable preterición de la legitimación activa de personas ... que, teniendo la consideración real de perjudicados por el fallecimiento de una per- 
sona (por padecer realmente un daño moral), sin embargo, no podrán hacerlo valer ante los Tribunales, a tenor de los términos del planteamiento de la cuestión que se examina. El derecho fundamental a la tutela judicial efectiva reconocido en el art. 24.1 CE, se impone al legislador ex art. 53.1 CE. Tal derecho va referido objetivamente a los derechos e intereses legítimos que operan, así, como presupuesto del citado derecho: allí donde existan esos derechos e intereses legítimos necesariamente el legislador deberá abrir el cauce de la tutela judicial efectiva con los contenidos que desde la primera formulación del TC se ha venido atribuyendo a este derecho fundamental: acceso a la jurisdicción para, con las garantías del art. $24 \mathrm{CE}$, obtener una resolución razonada y fundada en Derecho, con exigibilidad de su ejecución (SSTC 26/1983, FJ 2; 10/2000, FJ 2; 83/2001, FJ 4, y 3/2004, FJ 3), siendo de destacar que este derecho no garantiza en ningún caso la estimación de las pretensiones deducidas (STC 9/2005, FJ 3). El ordenamiento jurídico atribuye derechos subjetivos y de él derivan intereses legítimos. Reconocidos éstos, si el legislador les negase el acceso a la tutela judicial efectiva se vulneraría el art. 24 CE. Si el legislador no los recoge, si les niega la condición de derechos e intereses legítimos podrán vulnerarse otros preceptos constitucionales, pero no, desde luego, el art. 24.1 CE. La ley no tiene una ilimitada libertad para el reconocimiento de los mencionados derechos o intereses sustantivos, pero no es del art. 24.1 CE de donde proceden los límites aquí relevantes, sino de otros preceptos de la Constitución. No existe un concepto constitucional de perjudicado ni de beneficiario de la indemnización en la materia regulada por los preceptos cuestionados; ninguna exigencia constitucional impone que toda persona que sufra un daño moral por la muerte de alguien en accidente de circulación haya de ser indemnizada. Los preceptos legales que regulan esta materia han de respetar las exigencias de diversas normas constitucionales: las del principio de igualdad (art. $14 \mathrm{CE}$ ), para atribuir a un sujeto esa condición. Pero del art. 24.1 CE no se deduce que nadie deba recibir la consideración de perjudicado o de beneficiario de la indemnización, sino que lo que impone el derecho a la tutela judicial efectiva es que quien ostente dicha condición por atribución constitucional o legal sea tutelado en esa condición por los jueces. Lo que exige el derecho a la tutela judicial no es que los derechos adquieran una determinada dimensión sustantiva, sino que una vez delimitada ésta, no existan obstáculos artificiales para su defensa en juicio. Por todo ello concluye el TC que lo que la tabla I podrá impedir a las personas que no figuran en ella es la obtención de una Sentencia estimatoria, pero esto no es obviamente un contenido del derecho a la tutela judicial efectiva, que no garantiza en ningún caso la estimación de las pretensiones deducidas (STC 9/2005, FJ 3). En relación con el último motivo de inconstitucionalidad, la invasión de la reserva jurisdiccional, con cita del art. 117.1 CE, aunque seguramente se refiere al art. 117.3 CE. En el Auto este motivo se reconduce a los dos anteriores, pues se considera trasfondo común o paisaje del fondo de las alegadas vulneraciones de los arts. 14 y 24.1 CE. Tal invasión se produce porque la regulación cues- 
tionada ha sustituido lo que es la genuina función jurisdiccional de actuación del Derecho objetivo al caso concreto, por la anticipada decisión legislativa de quién sea perjudicado, al margen del examen de cada situación personal por quienes están llamados a efectuar la ponderación y estimación correspondiente según lo alegado y pro$b a d o$, a tenor del cuestionante. A esta cuestión ya respondió el TC en la citada STC 181/2000 (FJ 19): del principio de exclusividad de Jueces y Magistrados en el ejercicio de la potestad jurisdiccional (art. 117.3 CE) no puede inferirse la existencia de una correlativa prohibición impuesta al legislador, por la que se condicione su libertad de configuración para elegir el nivel de densidad normativa con que pretende regular una determinada materia; declaración que cabe proyectar sobre todos los aspectos de la relación jurídica derivada del acontecimiento dañoso, entre ellos, los subjetivos o personales, para descartar la pretendida vulneración de la invocada reserva jurisdiccional. Todo lo razonado, conduce a la desestimación de la cuestión de inconstitucionalidad formulada.

\section{B. Derechos y deberes de los ciudadanos.}

\section{Sentencia 213/2005, de 21 de julio (BOE de 18 de agosto). Ponente: Pérez Tremps (Cuestión de inconstitucionalidad).}

Preceptos constitucionales: 14, 35 y 41.

otros:

Objeto: Apartado 3 del art. 203 de la Ley general de la Seguridad Social, texto refundido aprobado por Real Decreto Legislativo 1/1994, de 20 de junio, en la redacción dada por el art. 40 de la Ley 66/1997, de 30 de diciembre, de medidas fiscales, administrativas y de orden social,

Materias: Derecho al trabajo. Principio de igualdad. Derecho a las prestaciones de seguridad social.

El objeto de la presente cuestión de inconstitucionalidad es determinar si el precepto citado en el Objeto vulnera los arts. 14 y 35 CE, en relación con el art. $41 \mathrm{CE}$ al limitar la protección por desempleo parcial a los supuestos de reducción temporal de jornada autorizados por un período de regulación de empleo. La contingencia de desempleo parcial a la que afecta la regulación cuestionada hace referencia a aquélla en la que el trabajador, sin perder su empleo, ve, sin embargo, reducida su jornada de trabajo con pérdida proporcional del salario. En su actual regulación no reviste ya ninguna duda el hecho de que la voluntad del legislador es configurar el desempleo parcial como contingencia protegida en relación únicamente con los supuestos de reducción de jornada autorizados de forma temporal por la au- 
toridad laboral como medida de regulación de empleo, dejando por el contrario fuera de dicha cobertura a las reducciones definitivas o de duración indefinida decididas por el empresario al amparo del art. 41 LET. Es esta diferenciación legal la que determina el objeto de la presente cuestión de inconstitucionalidad. Sin embargo en el momento de intentar resolver esta cuestión la situación no es ya la descrita; a raíz de la nueva regulación del contrato a tiempo parcial introducida en el art. 12 LET por el Real Decreto-ley 39/1998, de 27 de noviembre, dejó de ser posible al amparo del art. 41 LET una reducción de la jornada de trabajo en más de un tercio de su duración impuesta al trabajador en contra de su voluntad, dado que una tal reducción de jornada implicaría la conversión del contrato a tiempo completo en un contrato a tiempo parcial y tal conversión tendrá siempre carácter voluntario para el trabajador, y no se podrá imponer de forma unilateral o como consecuencia de una modificación sustancial de condiciones de trabajo [art. 12.4 e) LET], de manera que la exclusión legal de la protección por desempleo de las situaciones derivadas de dichos supuestos habrá de ser valorada teniendo en cuenta el dato legal sobrevenido del carácter necesariamente voluntario para el trabajador de tales modificaciones. Mas aún tras la última reforma de la definición legal del contrato a tiempo parcial operada por la Ley 12/2001, de 9 de julio, a partir de la cual cualquier reducción de jornada por debajo de la ordinaria implica la conversión del contrato a tiempo completo en un contrato a tiempo parcial y, por lo tanto, conlleva necesariamente la exigencia de voluntariedad en la reducción y la exclusión de la aplicación del art. 41 LET. El Auto de planteamiento de la cuestión imputa al precepto objeto de ella la vulneración de los arts. 14 y $35 \mathrm{CE}$, en relación con el art. 41 del mismo texto constitucional, que recoge la garantía del mantenimiento por los poderes públicos de un régimen público de Seguridad Social para todos los ciudadanos, que garantice la asistencia y prestaciones sociales suficientes ante situaciones de necesidad, especialmente en caso de desempleo. En relación con la doctrina del TC referida al art. $41 \mathrm{CE}$, conviene precisar lo siguiente: (a) La Constitución ha recogido y consagrado en su art. 41 la evolución que han experimentado los sistemas contemporáneos de Seguridad Social, de tal suerte que la protección de los ciudadanos ante situaciones de necesidad se concibe como una función del Estado, rompiéndose en buena parte la correspondencia prestación-cotización propia del seguro privado, superada por la dinámica de la función protectora de titularidad estatal (SSTC 103/1983, FJ 3; 65/1987, FJ 17). (b) El art. 41 CE impone a los poderes públicos la obligación de establecer -o mantener- un sistema protector que se corresponda con las características técnicas de los mecanismos de cobertura propios de un sistema de Seguridad Social; el referido precepto consagra en forma de garantía institucional un régimen público cuya preservación se juzga indispensable para asegurar los principios constitucionales, estableciendo ... un núcleo o reducto indisponible por el legislador (STC 32/1981, FJ 3), de tal suerte que ha de ser preservado en términos reconoscibles para la imagen que de la misma tiene la conciencia social en cada tiempo y lugar (STC 
26/1987, FJ 4; y 76/1988, FJ 4). (c) Salvada esta indisponible limitación, el derecho que los ciudadanos puedan ostentar en materia de Seguridad Social es un derecho de estricta configuración legal, disponiendo el legislador de libertad para modular la acción protectora del sistema en atención a circunstancias económicas y sociales que son imperativas para la propia viabilidad y eficacia de aquél (STC 65/1987, FJ 17). El Auto de planteamiento de la cuestión no denuncia la vulneración autónoma por el precepto legal cuestionado del art. $41 \mathrm{CE}$, sino la del art. $14 \mathrm{CE}$ en relación con el citado art. $41 \mathrm{CE}$. Con ello viene a plantearse, en definitiva, que, si bien el art. 41 CE no obliga a dar protección a las situaciones de desempleo parcial, si el legislador asume y desarrolla la protección por tal contingencia, no puede hacerlo excluyendo de la misma a supuestos idénticos o incluso más graves desde el punto de vista de la necesidad de protección que los incluidos, por afectar con ello al derecho a la igualdad en la ley del art. $14 \mathrm{CE}$, resulta conveniente precisar que una reducción de la jornada de trabajo, ya sea de carácter temporal o de duración indefinida, no comporta la pérdida del empleo. El trabajador que ve reducida su jornada de trabajo mantiene su empleo y, por lo tanto, no es propiamente un trabajador desempleado. Es cierto que la norma utiliza la expresión desempleo parcial para aludir a esta situación, distinguiéndola así de la situación de desempleo total que tiene su origen en la extinción del contrato, como es cierto también que la regulación de la situación legal de desempleo (art. 208 LGSS) incluye en su definición este supuesto de reducción de la jornada. Lo que interesa resaltar es que la desigualdad de tratamiento que la cuestión de inconstitucionalidad denuncia no se produce en la cobertura de un estado de necesidad derivado de una situación de desempleo (art. $41 \mathrm{CE}$ ), sino en la compensación del perjuicio salarial resultante de una decisión empresarial de reducción de jornada. Comenzará el TC su análisis por el de la vulneración del derecho a la igualdad en la ley (art. $14 \mathrm{CE}$ ): el TC tiene declarado, desde la STC 22/1981, recogiendo al respecto la doctrina del Tribunal Europeo de Derecho Humanos, que el principio de igualdad no implica en todos los casos un tratamiento legal igual con abstracción de cualquier elemento diferenciador de relevancia jurídica, de manera que no toda desigualdad de trato normativo respecto a la regulación de una determinada materia supone una infracción del mandato contenido en el art. $14 \mathrm{CE}$, sino tan sólo las que introduzcan una diferencia entre situaciones que puedan considerarse iguales, sin que se ofrezca y posea una justificación objetiva y razonable para ello, pues, como regla general, el principio de igualdad exige que a iguales supuestos de hecho se apliquen iguales consecuencias jurídicas y, en consecuencia, veda la utilización de elementos de diferenciación que quepa calificar de arbitrarios o carentes de una justificación razonable. Lo que prohíbe el principio de igualdad, en suma, son las desigualdades que resulten artificiosas o injustificadas por no venir fundadas en criterios objetivos y razonables, según criterios o juicios de valor generalmente aceptados. También es necesario, para que sea constitucionalmente lícita la diferencia de trato, que las consecuencias jurídicas que se deriven de tal distinción sean proporcionadas a la finalidad perseguida, de suerte que se eviten resultados excesivamente gravo- 
sos o desmedidos (SSTC 200/2001, FJ 4, y 88/2005, FJ 5). Lo específico de este juicio, es su carácter relacional conforme al cual se requiere como presupuestos obligados, de un lado, que, como consecuencia de la medida normativa cuestionada, se haya introducido directa o indirectamente una diferencia de trato entre grupos o categorias de personas (STC 181/2000, FJ 10) y, de otro, que las situaciones subjetivas que quieran traerse a la comparación sean, efectivamente, homogéneas o equiparables, es decir, que el término de comparación no resulte arbitrario o caprichoso (SSTC 148/1986, de 25 de noviembre, FJ 6; 29/1987, de 6 de marzo, FJ 5; 1/2001, de 15 de enero, FJ 3). Sólo una vez verificado uno y otro presupuesto resulta procedente entrar a determinar la licitud constitucional o no de la diferencia contenida en la norma (STC 200/2001, FJ 5). En definitiva, como ha sintetizado la STC 125/2003 el principio de igualdad prohíbe al legislador configurar los supuestos de hecho de la norma de modo tal que se dé trato distinto a personas que, desde todos los puntos de vista legítimamente adoptables, se encuentran en la misma situación o, dicho de otro modo, impidiendo que se otorgue relevancia jurídica a circunstancias que, o bien no pueden ser jamás tomadas en consideración por prohibirlo asi expresamente la propia Constitución, o bien no guardan relación alguna con el sentido de la regulación que, al incluirlas, incurre en arbitrariedad y es por eso discriminatoria; sólo ante iguales supuestos de hecho actúa la prohibición de utilizar elementos de diferenciación que quepa calificar de arbitrarios o carentes de una justificación razonable (STC 39/2002, FJ 4), razón por la cual toda alegación del derecho fundamental a la igualdad precisa para su verificación un tertium comparationis frente al que la desigualdad se produzca, elemento de contraste que ha de consistir en una situación jurídica concreta en la que se encuentren otros ciudadanos u otros grupos de ciudadanos (ATC 209/1985, FJ 2); de ahí la necesidad de examinar si los supuestos de hecho aportados por el órgano judicial como término de comparación guardan la identidad que todo juicio de igualdad requiere. Respecto del 1 derecho a la igualdad con relación a las prestaciones del sistema de la Seguridad Social, es doctrina del TC, sintetizada en la STC 197/2003, FJ 3, que el art. 41 CE convierte a la Seguridad Social en una función estatal en la que pasa a ocupar una posición decisiva el remedio de situaciones de necesidad, pero tales situaciones han de ser apreciadas y determinadas teniendo en cuenta el contexto general en que se producen y en conexión con las circunstancias económicas, las disponibilidades del momento y las necesidades de los diversos grupos sociales. No puede excluirse por ello que el legislador, apreciando la importancia relativa de las situaciones de necesidad a satisfacer, regule, en atención a las circunstancias indicadas, el nivel y condiciones de las prestaciones a efectuar o las modifique para adaptarlas a las necesidades del momento (STC 65/1987, de 21 de mayo, FJ 17). Los arts. 41 y 50 CE no constriñen al establecimiento de un único sistema prestacional fundado en principios idénticos, ni a la regulación de unos mismos requisitos o la previsión de iguales circunstancias determinantes del nacimiento de los derechos reconocibles al amparo de los principios constitucionales (SSTC 65/1987, de 21 de mayo, FJ 17 y 149/2004, de 20 de septiembre, FJ 5, entre otras). En definitiva, como advierte la STC 197/2003, FJ 6 in fine, si bien la cobertura de las situaciones de necesidad de los colectivos sociales 
es un ideal claramente deseable a la luz de los principios rectores de la politica social y económica que nuestra Constitución asume en sus arts. 41 y 50 y que han de informar la legislación positiva -art. 53.3 CE-" sin embargo este Tribunal Constitucional no debe interferir con decisiones singularizadas susceptibles de alterar el equilibrio económico financiero del conjunto del sistema, salvo que la diferencia de tratamiento controvertida esté desprovista de toda justificación objetiva y razonable (STC 184/1993, FJ 6)". Desde estos presupuestos, analizará el TC la cuestión planteada: Se trata de verificar el diferente tratamiento en términos de protección otorgado por el legislador social a las reducciones de jornada, según que se trate de reducciones autorizadas con carácter temporal por la autoridad laboral al amparo de los arts. 47 y 51 LET, en el marco de un procedimiento de regulación de empleo, o de reducciones derivadas de la modificación sustancial del contrato de trabajo decidida por el empresario, con alcance permanente o indefinido, al amparo del art. 41 LET y en virtud de alguna de las causas previstas en el mismo, diferente tratamiento que se materializa básicamente en el reconocimiento a los primeros del derecho a unas prestaciones por desempleo parcial, prestaciones que no se reconocen, por el contrario, a los segundos. Es criterio del TC que no es en realidad la duración de la situación el criterio tenido en cuenta por el legislador para articular la protección, como lo demuestra el hecho de que se incluyan entre las situaciones no cubiertas las derivadas de aquellas reducciones de jornada aplicables hasta la finalización de los contratos temporales, reducciones que, por hipótesis, pueden ser de muy corta duración, sino su carácter transitorio o su conexión con una medida de ajuste coyuntural del empleo en la empresa. Lo que hace el art. 203.3 LGSS es reconocer el acceso a la protección por desempleo parcial en las situaciones de reducción de la jornada de trabajo autorizadas por la autoridad laboral por un período de regulación de empleo, y no reconocerlo en las de modificación sustancial de condiciones de trabajo decididas por el empresario al amparo del art. 41 LET, aunque la modificación consista en una reducción de la jornada de trabajo. Con estas precisiones pasa el TC a analizar la eventual desigualdad plateada. (a) Las reducciones de jornada temporales a las que se refiere el art. 203.3 LGSS forman parte del conjunto de medidas de regulación de empleo que pueden adoptar las empresas, previa autorización administrativa, para la superación de situaciones económicas negativas o de riesgo para la viabilidad de la empresa (art. 47 en relación con el art. 51 LET). Al igual que las suspensiones de contratos a las que se refiere el art. 47 LET, las reducciones de jornada forman parte de las medidas de alcance puramente transitorio o temporal, que persiguen lograr la superación de una de dichas situaciones sin afectar al mantenimiento de los puestos de trabajo. El tratamiento legal de los supuestos de reducción de jornada por regulación de empleo es idéntico al establecido para los supuestos de suspensión de contratos por igual motivo, en todos los aspectos, incluido el de la protección por desempleo. De hecho, difícilmente podría ser de otra forma teniendo en cuenta que, en virtud de la vigente regulación legal en materia de orde- 
nación del tiempo de trabajo (arts. 34 y ss. LET) y de las posibilidades de cómputo anual y distribución irregular de la jornada que en dicha regulación legal se establecen, las diferencias entre una suspensión de contratos y una reducción de jornada resultan de hecho inexistentes o poseen un alcance meramente nominal. Frente a este carácter marcadamente coyuntural de las medidas de regulación de empleo, una modificación (reducción, en este caso) de la jornada de trabajo operada a través del mecanismo previsto en el art. 41 LET determina que el contrato de trabajo inicialmente existente resulte modificado en lo que se refiere a la jornada y el salario se ajusta a las nuevas especificaciones que constituyen el objeto de la modificación. Además, cuando el contrato en el que se reduce la jornada hubiera sido inicialmente concertado a tiempo completo, como ocurre en el caso del que dio origen a la presente cuestión de inconstitucionalidad, la modificación va mas allá de la mera alteración de una de las condiciones de trabajo, para alcanzar a alterar el tipo mismo de modalidad contractual, que pasará a ser un contrato a tiempo parcial sometido a un régimen jurídico específico, contenido, en lo fundamental, en el art. 12 LET. El nuevo contrato resultante de esta modificación no difiere en nada de otro contrato a tiempo parcial que hubiera sido pactado desde un principio con esas mismas especificaciones de jornada y salario. Por ello, a la hora de analizar la necesidad de cobertura por el sistema de protección por desempleo de esta situación el elemento de referencia no es en realidad el contrato resultante en sí, pues en un contrato idéntico que hubiera sido formalizado inicialmente a tiempo parcial no se pretende tal cobertura, sino el hecho mismo de la modificación y el perjuicio -básicamente, la pérdida de ingresos- que ocasiona al trabajador. La regulación del art. 41 LET que ofrece el legislador de 1994 trata de conciliar, el reconocimiento de las facultades derivadas de la necesidad de adaptabilidad de las empresas con la garantía de los derechos de los trabajadores frente a modificaciones arbitrarias. A tal efecto, el legislador diseña un sistema que faculta al empresario para la adopción de este tipo de modificaciones en virtud de causas tasadas y de acuerdo con un determinado procedimiento diferenciado según el carácter individual o colectivo de la modificación, con sujeción a un eventual posterior control judicial sobre el carácter justificado o injustificado de la modificación y con el reconocimiento del derecho del trabajador perjudicado de instar la rescisión de su contrato de trabajo con derecho a indemnización, lo que sitúa la cuestión en un terreno prácticamente idéntico al de un despido por motivos justificados pero ajenos a la conducta del trabajador. (b) De acuerdo con su configuración legal, es también diferente el tipo de causas que justifican una y otra medida. Aun cuando en ambos casos se trate de causas de naturaleza objetiva identificadas por referencia a unas denominaciones comunes -causas económicas, técnicas, organizativas o de producción- es lo cierto que la ley introduce diferencias significativas a la hora de valorar la concurrencia de unas y otras según su aptitud para justificar una medida de regulación de empleo o una de modificación de las condiciones de trabajo. 
(c) Esta diferente función atribuida a unas y otras medidas se corresponde también con la diferencia de régimen jurídico. En particular, la exigencia de autorización administrativa en el caso de los expedientes de regulación de empleo, a diferencia de lo establecido en el caso de la modificación de condiciones del art. 41 LET, en el que la decisión es adoptada exclusivamente por el empresario -en su caso, tras la celebración de un período de consultas- y resulta directamente ejecutiva, sin perjuicio de su posible impugnación judicial (art. 41.3 LET). El eventual control judicial posterior sobre el carácter justificado o injustificado de la medida no constituye una garantía a los efectos del art. 51.5 LET citado, entre otras razones porque sólo actúa a iniciativa del propio trabajador. (d) Desde la perspectiva del trabajador existe también una diferencia sustancial entre una y otra medida, cual es la relativa a la imperatividad de la decisión empresarial en cada uno de los supuestos. En el caso de la reducción establecida como medida coyuntural de regulación de empleo, la decisión debe ser forzosamente aceptada por el mismo, entendiendo evidentemente este carácter forzoso en el sentido preciso de que la decisión empresarial no constituye causa justificada para que el trabajador pueda instar la rescisión de su contrato de trabajo. Por el contrario, en el caso de la modificación sustancial decidida al amparo de lo dispuesto en el art. 41 LET, el trabajador que resulte perjudicado por la modificación tiene derecho a rescindir su contrato de trabajo percibiendo una indemnización de veinte días de salario por año de servicio. Esta indemnización, que equipara en gran medida este supuesto al de los despidos objetivos (arts. 52 y 53 LET), implica, por lo que aquí interesa, que el trabajador que se enfrenta a una decisión empresarial de esta naturaleza que objetivamente le perjudique puede adoptar una de estas dos decisiones: o bien aceptar la modificación y continuar su relación laboral desde las nuevas bases modificadas, o bien decidir que su contrato ha quedado extinguido por causas imputables al empresario y con derecho a ser indemnizado por ello. (e) En cuanto a la situación resultante y la posibilidad de su cobertura a través del sistema de protección por desempleo, tampoco es equiparable la problemática que se plantea en uno y otro caso. Por una parte, como ya se ha señalado, la involuntariedad de la situación legal de desempleo puede entenderse garantizada, a través de diversos mecanismos, en los expedientes de los arts. 47 y 51 LET, pero no en las modificaciones sustanciales del art. 41. Si bien ambos instrumentos tienen en común una indudable dificultad de encaje en un sistema de protección que atiende básicamente a situaciones de carencia de empleo, y en el que las excepciones de compatibilización de las prestaciones con el trabajo plantean siempre numerosos problemas, estas dificultades no actúan de la misma manera en uno y otro caso. La disponibilidad del trabajador para el mercado de trabajo, la búsqueda activa de empleo, la obligación de aceptar una oferta de empleo adecuada, la participación en acciones de motivación, información, orientación, formación, reconversión o inserción profesionales y, en definitiva, el compromiso de actividad del que habla el art. 231.2 LGSS, resultan condicio- 
nantes difícilmente ajustables a una situación de novación contractual como la caracterizada por una reducción de la jornada de trabajo realizada al amparo del art. 41 LET, en mucha mayor medida que en el caso de la situación meramente coyuntural y sujeta al control de la autoridad laboral de los supuestos de regulación de empleo y con mayor dificultad también que en el caso de las situaciones de pluriempleo, en el que la existencia en todo caso de la extinción de una relación laboral actúa en sentido favorable a la lógica del sistema. El análisis de las dos instituciones comparadas pone de relieve que la naturaleza misma de la alteración de la relación laboral que se produce en uno y otro supuesto, las causas que la justifican, el alcance del control público sobre la concurrencia de dichas causas y las posibilidades de reacción de los trabajadores disconformes con la modificación operada en cada caso constituyen diferencias sustanciales que van mucho mas allá de la mera diversidad del alcance temporal de la medida a la que alude el órgano judicial y que impiden comparar las situaciones jurídicas resultantes de la actuación de cada uno de los mecanismos. Desde esta apreciación, no resulta objetable desde el art. 14 CE la decisión del legislador de articular de forma diferenciada la consideración y protección de los derechos de los trabajadores en cada uno de los supuestos, ni la de utilizar, en el caso de uno de ellos, el instrumento del sistema de protección por desempleo para compensar la reducción transitoria de los salarios. Desde la perspectiva analizada no parece casual, ni que responda a una consideración meramente formal, el que la ley reserve el reconocimiento de las prestaciones por desempleo a aquella medida que se configura como de regulación de empleo y que constituye un mecanismo de ajuste cuantitativo de los volúmenes de empleo; y que, frente a ello, otorgue un tratamiento legal diferente y basado en una lógica puramente contractual a aquellas medidas de flexibilidad y de adaptación cualitativa de las condiciones de trabajo adoptadas por la empresa en el ejercicio de sus facultades de gestión mediante la modificación de los contratos de trabajo. En conclusión, y por lo que se refiere al primero de los términos de comparación propuestos por el órgano judicial, existen, efectivamente, diferencias en el tratamiento que la ley otorga a ambas situaciones, pero estas situaciones no son comparables entre sí. La disparidad normativa encuentra su justificación en una opción legislativa legítima que limita el reconocimiento de la situación de desempleo parcial a aquellos supuestos que configuran una situación meramente coyuntural derivada de determinadas y específicas circunstancias empresariales y con el control de la autoridad laboral, y en los que el reconocimiento de la prestación actúa compensando la disminución transitoria de ingresos sufrida por el trabajador y facilitando, por ello, el desarrollo de la medida de regulación de empleo y el logro de los objetivos perseguidos con la misma. Por el contrario, el legislador considera ajena a la configuración del sistema la cobertura de aquellos supuestos en los que la reducción de jornada, por su carácter definitivo, implica una nueva situación económica y profesional en la que el trabajador seguirá desarrollando en el futuro su trabajo con unas nuevas 
condiciones de jornada y salario y, bajo una modalidad contractual distinta, consideración en la que legítimamente puede intervenir el criterio de que el reconocimiento de la prestación en tales supuestos resultaría contradictorio con la naturaleza misma de la contingencia, carecería en gran parte de los casos de toda posibilidad de control, e implicaría, en última instancia, una disparidad de trato con respecto a los trabajadores inicialmente contratados a tiempo parcial, que no se lucran de tal prestación salvo que hayan accedido al nuevo contrato de trabajo desde una previa situación de desempleo protegido. Si no resultan comparables entre sí las situaciones de reducción de jornada, menos aún puede encontrarse un término adecuado de comparación en el tratamiento legal de las situaciones de pluriempleo. En efecto, el trabajador pluriempleado o en situación de pluriactividad que pierde uno de sus empleos se encuentra respecto del empleo perdido en la situación de desempleo total que constituye la contingencia prevista en el art. 203.2 LGSS. El que la pérdida de uno de los empleos del trabajador pluriempleado pueda ser descrita gráficamente, como hace el Auto de planteamiento de la cuestión, en términos de reducción de su "tiempo de actividad laboral" no permite confundir ambas situaciones ni exigir, por aplicación del art. 14 CE, un idéntico tratamiento jurídico, pues en el caso del trabajador pluriempleado la situación legal de desempleo no se produce por la reducción de su jornada de trabajo, sino por la extinción de su contrato. El ordenamiento no contempla la situación de pluriempleo ni en el momento del nacimiento de la relación laboral ni respecto de su dinámica y desarrollo, con excepción de la jornada máxima establecida por razones de salud y seguridad en el caso de los menores de edad (art. 34.3 LET). En consecuencia, no pueden establecerse tampoco diferencias a la hora de analizar estas pérdidas de empleo en relación con el acceso a la protección por desempleo, por cuya cobertura se ha cotizado específicamente, aplicándose las reglas generales del sistema y limitándose las especificidades de la regulación legal a contemplar la situación resultante desde la óptica de la compatibilidad entre la prestación causada y el empleo aún mantenido, en la que sí plantea problemas específicos. En definitiva, no tratándose de situaciones iguales a efectos de la aplicación del art. $14 \mathrm{CE}$ la del trabajador pluriempleado que pierde uno de sus empleos y la de quien, manteniendo el suyo, ve reducida definitivamente su jornada de trabajo, no es objetable que ambas situaciones reciban, desde la lógica del sistema de protección por desempleo, un tratamiento diferenciado. Respecto de la posible vulneración del art. $35 \mathrm{CE}$, en relación con el derecho al trabajo y el principio de estabilidad en el empleo, lo cierto es que del tenor de la resolución judicial se desprende que la referencia al art. 35 CE no pasa de ser una alusión meramente retórica, carente de todo desarrollo autónomo en relación con el eje central de la cuestión. La invocación del art. $35 \mathrm{CE}$, que se realiza por primera vez por el órgano judicial en el Auto de planteamiento, no habiéndose aludido a dicho derecho constitucional en la providencia de 15 
de septiembre de 1998 por la que se dio audiencia a las partes sobre la pertinencia de plantear la cuestión de inconstitucionalidad, parece mas bien un recurso dialéctico dirigido a dar contestación a algunos de los argumentos esgrimidos por la representación procesal del INEM y por el Ministerio Fiscal respecto de las diferencias existentes entre las dos situaciones comparadas que una auténtica invocación de vulneración constitucional. Es claro que el art. 203.3 LGSS se limita a definir la situación de desempleo parcial como objeto de la protección por desempleo, sin abordar en absoluto cuestiones relacionadas con la regulación del contrato de trabajo o con el derecho al trabajo y a la estabilidad en el empleo. Resulta preciso resaltar que el derecho reconocido al trabajador en el art. 41 LET de solicitar la extinción indemnizada de su contrato no contradice su derecho al trabajo. Ante una modificación sustancial de condiciones de trabajo que perjudique al trabajador, éste puede decidir no aceptar dicha modificación o puede optar por mantener su puesto de trabajo a pesar de que estime perjudiciales o menos favorables las nuevas condiciones establecidas. El hecho de que en este segundo supuesto la ley no le otorgue el derecho a percibir prestaciones por desempleo parcial en modo alguno afecta a su derecho individual al trabajo y a la estabilidad en el empleo constitucionalmente reconocido. Concluirá el TC que la inclusión entre las situaciones cubiertas por el sistema de protección por desempleo de las reducciones de jornada operadas a través de una modificación sustancial de las condiciones de trabajo al amparo del art. 41 LET, de acuerdo con el marco jurídico que se encontraba vigente en la fecha de los hechos que dieron lugar a la presente cuestión de inconstitucionalidad, constituye una cuestión que atañe a la libertad de configuración del sistema de Seguridad Social que corresponde al legislador. La no inclusión en el sistema (art. 203.3 LGSS) de estas situaciones no vulnera tampoco el art. $14 \mathrm{CE}$, por relación a la situación de quienes ven reducida temporalmente su jornada de trabajo en el marco de una medida de regulación de empleo o de quienes, encontrándose pluriempleados, pierden uno de sus empleos, que sí son objeto de dicha inclusión, dadas las diferencias existentes entre una y otras situaciones que impiden declarar, desde la óptica del precepto constitucional, la exigencia de un tratamiento igual. Finalmente, no se aprecia tampoco que esta exclusión vulnere el derecho al trabajo del art. 35 CE. Resulta, por ello, obligado desestimar la cuestión de inconstitucionalidad.

\section{INSTITUCIONES DEL ESTADO.}

\section{B. Las Cortes Generales.}

1. Sentencia 155/2005, de 9 de junio (BOE de 8 de julio). Ponente: Conde Martín de Hijas (Recursos de inconstitucionalidad acumulados). 
Preceptos constitucionales: 74; 94.1.

otros:

Objeto: Real Decreto-ley 14/1998, de 9 de octubre, de adhesión de España a diversos Acuerdos del Fondo Monetario Internacional y contra los arts. 2 y 3, así como contra la Ley 13/1999, de 21 de abril, de adhesión de España a diversos Acuerdos del Fondo Monetario Internacional y, en especial, contra los arts. 2 y 3 .

Materias: Procedimiento para la autorización de suscripción de convenios internacionales. Diferenciación con el procedimiento legislativo ordinario.

La cuestión planteada en este procedimiento con carácter principal es si el Real Decreto-ley 14/1998 se ajusta a los límites sustantivos que resultan de los arts. 94.1 d) y 74.2, en relación con el art. 86 CE. También se discute por las partes si concurren los presupuestos circunstanciales establecidos por el último de estos preceptos para la emisión de un decreto-ley, así como cuáles sean los términos en que se relacionan los decretos-leyes y sus eventuales leyes de conversión, siendo aquélla la cuestión primera y medular, cuya suerte condiciona el enjuiciamiento de las restantes. Con carácter previo, es preciso despejar posibles dudas acerca de una eventual desaparición sobrevenida del objeto del recurso de inconstitucionalidad dirigido contra el Real Decreto-ley 14/1998, que también podrían extenderse a una parte del recurso núm. 3247/1999, promovido contra la Ley 13/1999. Tales dudas pudieran venir motivadas por la conjunción de dos circunstancias: De un lado, la conversión del Real Decreto-ley 14/1998 en la Ley 13/1999 por la vía del art. 86.3 CE; de otro, el hecho de que la ratificación de la cuarta enmienda al Convenio constitutivo del FMI que ahí se autoriza haya sido también autorizada por las Cortes Generales mediante el procedimiento previsto en los arts. 94.1 d) y 74.2 de la Constitución. Ninguno de estos hechos impide un pronunciamiento sobre la constitucionalidad del repetido Real Decreto-ley; el TC siempre ha sostenido que es algo fuera de duda que el control del Decretoley en cuanto tal no está impedido por el hecho de la novación operada por la Ley, siguiendo lo que dispone el art. 86.3, pues el interés constitucional de ajustar el uso del instrumento del Decreto-ley al marco del art. 86.1 ... no puede considerarse satisfecho por la derivación del Decreto-ley hacia el cauce del art. 86.3, ya que si bien pudiera ...pensarse que una eficacia retroactiva de la Ley que diera cobijo a los efectos producidos por el Decreto-ley puede privar de sentido a la impugnación dirigida ... al Decreto-ley, ... esto no es así, pues ... velar por el recto ejercicio de la potestad de emitir Decretos-leyes, dentro del marco constitucional, es algo que no puede eludirse por la utilización del procedimiento del art. 86.3 (STC 111/1983, FJ 3; en el mismo sentido, STC 182/1997, FJ 1). El enjuiciamiento constitucional del citado decreto-ley es cuestión cuyo interés va más allá de la vigencia de sus preceptos, 
pues en otro caso sería imposible asegurar la observancia de las condiciones que el art. 86 establece específicamente para la emisión de decretos-leyes. La Constitución únicamente admite la legislación de urgencia bajo condiciones cuya inobservancia constituye una infracción que sólo puede repararse con una declaración de inconstitucionalidad, sin que los efectos derogatorios de la legislación sobrevenida o los convalidantes de la asunción del decreto-ley por el Congreso de los Diputados puedan corregir un defecto que ha de concebirse como necesariamente insubsanable, pues, en otro caso, los límites del art. 86 CE sólo serían operativos en el tiempo que media entre el decreto-ley y su convalidación o su conversión en ley, esto es, en un tiempo en el que el TC nunca podrá materialmente pronunciarse. Las mismas razones descartan la desaparición sobrevenida del objeto de la impugnación del art. 3 del Real Decreto-ley 14/1998 y del correspondiente de la Ley 13/1999. En la medida en que los actores entienden que la autorización de las Cortes Generales sólo puede dispensarse por la vía de los arts. 94.1 y $74.2 \mathrm{CE}$, y nunca por medio de ley formal, es claro que el hecho de que se hayan sucedido autorizaciones de igual contenido acordadas por uno y otro procedimientos no hace sino confirmar la existencia de un problema constitucional que cumple resolver. Se impugna formalmente el Real Decretoley 14/1998 y la Ley 13/1999 en su conjunto, pero indicando que se recurre en especial contra sus respectivos arts. 2 y 3 . Son dos motivos diferentes de inconstitucionalidad los que se alegan uno de índole material, referido a la veda material del Real Decreto-ley en relación con el contenido del mismo y otro atinente a la concurrencia de la circunstancia de la extraordinaria y urgente necesidad exigida por el art. 86.1 para la promulgación de decretos-leyes. Sobre esa base sólo en el caso de que se rechazase la objeción de índole material sería pertinente plantearse si concurre o no el supuesto circunstancial al que se refiere dicho artículo. En relación con el recurso dirigido contra el Real Decreto-ley 14/1998, debe recordarse que la norma impugnada es una norma jurídica con valor de ley a la que está vedada la afectación de las materias enunciadas en el art. 86.1 CE. Esa afectación no es el único límite sustantivo al que la Constitución somete a los decretos-leyes; sobre éstos opera también el conjunto de las reservas establecidas por el constituyente respecto de determinadas materias y en beneficio de específicas formas y procedimientos. Entre tales reservas figura la que para la prestación del consentimiento del Estado para obligarse por medio de tratados o convenios establece el art. 94.1 de la Constitución, en cuya virtud dicha prestación debe ser autorizada, en determinados casos, por las Cortes Generales. Queda excluida, por tanto, la posibilidad de una prestación de ese consentimiento sin previa autorización parlamentaria o con la dispensada por un órgano distinto. El decreto-ley no es una forma jurídica habilitada para la autorización requerida por el art. 94.1 CE. El art. 86.1 CE sólo prevé la figura del decreto-ley para dictar disposiciones legislativas, categoría jurídica que es distinta de la que corresponde a las autorizaciones, por lo que no puede considerarse instrumento idóneo para el acuerdo de autorizaciones. 
Por otra parte, tratándose de una autorización es claro que no puede concederla quien debe ser autorizado. Por último, el decreto-ley es una fuente normativa propia del Gobierno que sólo precisa de la intervención del Congreso de los Diputados para la estabilización de su vigencia en el Ordenamiento. Ni siquiera tras su convalidación parlamentaria es el decreto-ley una forma jurídica capaz de dispensar una autorización que sólo pueden brindar las Cortes Generales, de manera que no es posible ver en la convalidación un acto equivalente a la autorización requerida por el art. 94.1 CE. La autorización del art. 94.1 CE ha de ser previa a la prestación del consentimiento, lo que supone que si la autorización contenida en el decreto-ley sólo se perfecciona tras la convalidación parlamentaria, el decreto-ley no autorizaría per se la prestación del consentimiento y dejaría así de producir plenos efectos desde su publicación, lo que difícilmente se avendría con su condición de instrumento para la legislación de urgencia. La alternativa pasaría entonces por considerar suficiente la autorización contenida en el decretoley antes de su convalidación; esto es, la autorización estrictamente gubernamental, lo que a su vez sería manifiestamente contrario a la exigencia de una autorización que debe ser de las Cortes Generales y ha de concederse siempre antes de que el Estado se comprometa internacionalmente cuando se trata de los supuestos enunciados en el art. 94.1 CE. Admitir, por último, que el decreto-ley aún no convalidado es inicialmente bastante para autorizar la prestación del consentimiento pero que, sin embargo, la autorización sólo se perfecciona tras la convalidación de la norma del Gobierno, implicaría, al cabo, permitir la celebración de un tratado antes de su efectiva autorización parlamentaria (en todo caso incompleta, por quedar excluida una de las Cámaras). En consecuencia el Real Decreto-ley 14/1998 no es una norma capaz de dar forma jurídica a la autorización constitucionalmente necesaria para que el Estado se obligue internacionalmente mediante los tratados o convenios relacionados en el art. 94.1 CE. La cuestión que inmediatamente se impone es, por tanto, determinar si los arts. 2 y 3 de dicho Real Decreto-ley se refieren a convenios o tratados de esa naturaleza, en particular, y como alegan los recurrentes, a los referidos en el apartado d) del art. 94.1 CE, es decir, aquéllos que impliquen obligaciones financieras para la Hacienda Pública. En cuanto al art. 2 del Real Decreto-ley 14/1998, se sostiene que con la adhesión a los Nuevos Acuerdos para la obtención de préstamos del Fondo Monetario Internacional se establece un nuevo marco convencional que obliga a la hacienda pública española a poner recursos financieros a disposición del FMI mediante el otorgamiento de préstamos por un importe máximo de hasta 672 millones de derechos especiales de giro. En opinión del TC, llevan razón los recurrentes al mantener que el art. 2 del Real Decreto-ley se refiere a compromisos internacionales que suponen la asunción de obligaciones financieras por parte de la hacienda pública. En virtud de los Nuevos Acuerdos aprobados mediante la Decisión del Directorio del FMI de 27 de enero de 1997 los países que los suscriban adquieren un inequívoco compromiso en orden a facilitar al Fondo los prés- 
tamos que éste pueda precisar para poner a disposición de terceros los recursos financieros que les sean necesarios. Es evidente que las cantidades puestas a disposición del Fondo se anotarán en la cuenta de activo del Banco de España, como advierte el Abogado del Estado, pero ello es así como lógica consecuencia del compromiso previo de esa puesta a disposición, que, caso de hacerse efectiva, exigirá la correspondiente aportación dineraria, a la que el Estado se obliga. Debe advertirse que el sujeto al que inmediatamente se refiere el art. 2.1 del Real Decreto-ley es el Reino de España, que es por tanto el titular del compromiso establecido en el inciso segundo del art. 2.1. A su vez el apartado 2 de dicho artículo atribuye al Ministerio de Economía y Hacienda la adopción de decisiones para la efectividad de los Nuevos Acuerdos. En tales condiciones es indudable la afectación de la hacienda pública, independientemente de que la posterior instrumentación del compromiso se lleve a cabo por el Banco de España en los términos previstos en la disposición final primera. Los Nuevos Acuerdos referidos en el art. 2 del Real Decreto-ley no son mera consecuencia del normal desarrollo del Convenio constitutivo del Fondo Monetario Internacional. El art. 3 de dichos Nuevos Acuerdos deja claro que la adhesión a los mismos no es obligada para los Estados miembros del Fondo Monetario Internacional, sino que éstos podrán adherirse depositando al efecto un instrumento en que harán saber que su adhesión se ha realizado conforme a su legislación interna y que han adoptado las medidas necesarias para poder cumplir las condiciones de la presente decisión [apartado c)]. Los países miembros del Fondo no contraen, con la sola asunción del Convenio constitutivo, una obligación exigible ex art. VII, sección 1, de dicho Convenio, sino que las obligaciones de esa naturaleza requieren una adhesión específica para cada caso. No estamos, en consecuencia, en el caso de una obligación asumida inmediatamente con la integración del Convenio constitutivo, ni tampoco ante la necesidad de cumplir inexorablemente con un compromiso adquirido al tiempo de incorporar, con el Convenio, el procedimiento ordinario de adopción de decisiones del Fondo Monetario Internacional. Se trata de un nuevo compromiso en el marco de otro anterior desde el propio Convenio constitutivo, para exigir un pronunciamiento expreso de adhesión. Lo determinante es la existencia de un acuerdo, en cuya virtud el Estado se obliga frente a otros Estados en el marco del Derecho internacional. Constitucionalmente es irrelevante si ese compromiso se formaliza expresamente en un tratado o en la adhesión a una obligación nacida en el marco de un tratado que la hace posible pero no necesaria; lo determinante es que el Estado se comprometa a una conducta que hasta entonces no le era exigible en absoluto; y tal era el caso con las obligaciones a que se refiere el art. 2 del Real Decreto-ley examinado. En consecuencia, el art. 2 del Real Decreto-ley 14/1998 es inconstitucional por infracción del art. 94.1 d) de la Constitución. También se aprecia la inconstitucionalidad del art. 3 del Real Decreto-ley por cuanto en él se autoriza la ratificación de una enmienda al propio Convenio constitutivo del Fondo Monetario Internacional. Ahora no se trata de comprometer al Estado con 
obligaciones específicas en el marco de una obligación general, sino de modificar el texto normativo del que nace precisamente esta última, es decir, el Convenio al que se adhirió España en 1958. Aunque sea problemático determinar si nos encontramos ante compromisos internacionales, mera concreción de compromisos previos y más generales, cuya asunción implica la de aquéllos, o ante obligaciones que requieren de un consentimiento particular y expreso, se afirma que la modificación por vía de enmienda de un Convenio ya integrado, ex art. $96 \mathrm{CE}$, en el Ordenamiento nacional es una operación que sólo puede asumirse con las condiciones requeridas para la asunción de un nuevo compromiso; esto es, en los mismos términos en los que se asumió el Convenio de cuya modificación se trata o en los exigidos por la Constitución ahora vigente para la incorporación de un convenio de los previstos en el art. 94.1 CE. Sus características determinan la impropiedad de la figura del decreto-ley para autorizar la prestación del consentimiento del Estado a una revisión de la naturaleza de la realizada por obra de la cuarta enmienda, defecto que no pudo dejar de advertir el Gobierno, al iniciar para ella el procedimiento del art. 94.1 CE antes de promulgar el Real Decreto-ley 14/1998 y continuarlo aun después de su promulgación. Esa diferencia jurídica entre lo que supone la aprobación de las leyes y la autorización parlamentaria de tratados internacionales, ya se afirmó expresamente en el ATC 114/1991, de 11 de abril, FJ 3 in fine: la aprobación de las Leyes que configura el supuesto de hecho de tal precepto [se refiere expresamente al art. $91 \mathrm{CE}]$, es una figura jurídica esencialmente distinta de la autorización parlamentaria de los Tratados internacionales, que es la regulada por el art. 94 de nuestra Ley de Leyes. El art. 3 del Real Decreto-ley 14/1998 es igualmente inconstitucional por infracción del art. 94.1 d) CE. Apreciada la inconstitucionalidad de los arts. 2 y 3 del Real Decreto-ley 14/1998 por razón de su incompetencia material, carece de sentido examinar si concurre o no la circunstancia de extraordinaria y urgente necesidad exigida por el art. 86.1 CE para la promulgación de decretos-leyes. Por lo que se refiere a la Ley 13/1999, de 21 de abril se sostiene que la virtual identidad de contenido entre la Ley 13/1999 y el Real Decreto-ley 14/1998 responde a la intención de solventar con aquélla los defectos de constitucionalidad padecidos por éste en razón de su inidoneidad como instrumento normativo para dar curso a la autorización prevista en el art. 94.1 de la Constitución; ese efecto reparador nunca podría producirse, pues tampoco la Ley 13/1999 sería el cauce normativo constitucionalmente adecuado para formalizar la autorización previa del art. 94.1 CE, toda vez que la misma no podría instrumentalizarse a través de cualesquiera procedimientos parlamentarios -ni siquiera el legislativo-, sino sólo mediante el previsto en los arts. 94.1 y 74.2 de la Constitución. Las dudas de constitucionalidad planteadas en relación con la Ley 13/1999 tienen que ver con su aptitud para subsanar los defectos constitucionales del Real Decreto-ley 14/1998 y con su condición de norma capaz de dar forma a la autorización parlamentaria exigida por el art. 94.1 CE. Ambas cuestiones vienen determinadas en su solución por el hecho de que la materia ob- 
jeto de regulación en los arts. 2 y 3 del Real Decreto-ley 14/1998 ha de encuadrarse en la categoría de los tratados o convenios que impliquen obligaciones financieras para la Hacienda Pública [art. 94.1 d) CE]. Ello supone que la Ley 13/1999 no puede subsanar el defecto padecido por el Real Decreto-ley 14/1998, consistente en ser expresión de una voluntad que en ningún caso puede imputarse a las Cortes Generales, sino únicamente al Gobierno. Admitir otra cosa supondría que las Cortes Generales validarían una autorización gubernativa que, así subsanada, habría producido plenos efectos desde un principio y que, por tanto, habría sido suficiente para hacer posible la integración de una norma internacional, de manera que ésta se habría incorporado al Ordenamiento con anterioridad a la autorización del Parlamento. Las Cortes Generales no autorizarían previamente la integración, como quiere el art. 94.1 CE, sino que validarían una integración ya autorizada por el Gobierno y convalidada por el Congreso de los Diputados. De este modo además de privarse a las Cortes Generales de su competencia exclusiva para autorizar la incorporación de determinadas normas internacionales antes de que ésta efectivamente se produzca, se comprometería gravemente el diseño del control preventivo de constitucionalidad de los tratados establecido en el art. $95 \mathrm{CE}$, pues las Cortes Generales sólo tendrían ocasión de requerir una Declaración de este Tribunal acerca de la compatibilidad del tratado con la Constitución una vez que aquél ya hubiera sido objeto de compromiso por parte del Gobierno en el ámbito del Derecho internacional, y no antes como es propio de dicho control preventivo. La Ley 13/1999 es fruto de la voluntad de las Cortes Generales. Se trata, pues, de una norma imputable a la misma voluntad que la requerida por el art. 94.1 CE para la autorización previa de la prestación del consentimiento internacional del Estado. La competencia exclusiva de las Cortes Generales para autorizar esa prestación no es lo lesionado con el empleo de la ley, a diferencia de lo que sucede con la legislación gubernamental de urgencia. Pero debe señalarse que la autorización previa de las Cortes Generales regulada en el art. 94.1 CE corresponde al ejercicio de una competencia que la Constitución califica de no legislativa, de modo que no resulta constitucionalmente indiferente la utilización de un cauce constitucional para el ejercicio de una competencia, reservado constitucionalmente a un cauce distinto. La cuestión no es ya de si se ha prescindido o no de la intervención de un órgano, sino si la concreta competencia ejercida por éste lo ha sido por el cauce específicamente previsto por la Constitución a esos efectos. En definitiva, si la Constitución impone, en el caso de la autorización requerida para la asunción de compromisos internacionales, además de una reserva orgánica, una reserva de procedimiento, por tratarse de ejercicio de competencias constitucionales distintas. Para las autorizaciones previstas en el art. 94.1 CE, el art. 74.2 de la Constitución establece un procedimiento parlamentario específico y diverso del legislativo ordinario o común, del que singularmente le distingue la circunstancia de que la posición del Senado se define en términos de mayor equilibrio frente a la que habitualmente es propia del Congreso de 
los Diputados. Mientras que en el procedimiento legislativo es norma que, de acuerdo con el art. 90.2 CE, las discrepancias entre ambas Cámaras pueden resolverse en último término por decisión de la mayoría simple de la Cámara baja, en el caso del art. 94.1 se prevé que las discrepancias se superen por medio de una Comisión mixta compuesta de igual número de Diputados y Senadores, cuya propuesta debe ser aprobada por la mayoría de cada Cámara, imponiéndose finalmente, si la discrepancia persiste, la del Congreso de los Diputados, pero sólo y siempre por mayoría absoluta (art. 74.2 CE). Esa potenciación de la voluntad del Senado, en comparación con la más reducida en el procedimiento legislativo, determina el proceso de formación de la voluntad parlamentaria en términos que se separan de cuanto es común en el conjunto de los procedimientos de las Cortes Generales, confiriéndose a la participación de la Cámara alta en aquel proceso una relevancia verdaderamente excepcional en nuestro sistema parlamentario, caracterizado por un notorio bicameralismo imperfecto. En la misma línea de diversidad de los respectivos cauces constitucionales correspondientes al ejercicio de competencias distintas puede señalarse la diversa índole de la intervención del Rey en la sanción y promulgación de las leyes y en la manifestación del consentimiento del Estado para obligarse internacionalmente por medio de tratados, respectivamente establecidas en el art. 62 a) y en el art. 63.2 CE. A lo que debe añadirse el posible juego de control previo de inconstitucionalidad, previsto en los arts. 95.2 CE y 78 LOTC, respecto de los tratados y no así de las leyes. El procedimiento del art. 74.2 CE ofrece, en suma, caracteres de entidad relevante para configurarlo como reservado para la adopción del acuerdo exigido por el art. 94.1 CE, de manera que, en principio, es obligado entender que la autorización parlamentaria previa a la prestación del consentimiento internacional del Estado ha de conformarse por ese específico procedimiento. El procedimiento del art. 74.2 CE no puede dar cabida a cosa distinta que a la estricta autorización del art. 94.1 CE, siendo por completo improcedente para la formación de otras voluntades parlamentarias. Los arts. 2 y 3 de la Ley 13/1999 autorizan la adhesión de España a determinados Acuerdos del Fondo Monetario Internacional y la ratificación de la cuarta enmienda al Convenio constitutivo del FMI, pero el art. 2 y, de manera especial, los restantes preceptos de la Ley incluyen otras disposiciones cuyo contenido no se ajusta al continente de la simple autorización para la integración de normas foráneas. Por mínimo que sea el contenido normativo que las Cortes Generales consideren oportuno que acompañe a la autorización previa para la que son requeridas en virtud del art. 94.1 CE, el procedimiento parlamentario pertinente será el legislativo, común o especial, que venga impuesto por la materia a que dicho contenido se refiera. Tal ha sido, por lo demás, la práctica observada hasta ahora por las Cortes Generales con ocasión de los distintos aumentos de la cuota de España en el Fondo Monetario Internacional. incorporando a la autorización ex art. 94.1 CE propiamente dicha, una serie de disposiciones de ordenación interna que no podían encontrar perfecta cobertura en el procedimiento sin- 
gular del art. 74.2 CE. Ello no significa que la especificidad de este último procedimiento haya de ceder necesariamente ante el procedimiento legislativo, cuando así lo imponga la afectación de otras materias. Lo que se impone es la duplicidad de procedimientos, distinguiendo con claridad la autorización propiamente dicha y la tramitación parlamentaria de las medidas legislativas necesarias como consecuencia de la autorización, que siempre ha de ser anterior. En otro caso la utilización exclusiva de la ley como cauce jurídico en el que se reduzcan a unidad una autorización ex art. $94 \mathrm{CE}$, por un lado, y las medidas legislativas necesarias para la mejor integración de la norma externa, por otro, no deja de suponer el apartamiento del específico procedimiento establecido en la Constitución, y en tal sentido reservado, para dicha autorización.

VOTO PARTICULAR (Delgado Barrio): Se discrepa de la declaración de inconstitucionalidad del art. 2, porque, en primer lugar no se aprecia el incumplimiento del procedimiento constitucional ordenado para la autorización pretendida, que en todo caso, debe entenderse concedida en atención a la anuencia que significa la misma aprobación de la ley por ambas Cámaras. Y ello, es doctrina que ya en la STC 97/2002 FJ 2, se señaló: las normas constitucionales y parlamentarias que regulan la elaboración de las leyes tienen carácter instrumental respecto de uno de los valores superiores de nuestro ordenamiento, el del pluralismo político (art. $1.1 \mathrm{CE}$ ), de suerte que la 'inobservancia de los preceptos que regulan el procedimiento legislativo podría viciar de inconstitucionalidad la ley cuando esa inobservancia altere de modo sustancial el proceso de formación de la voluntad en el seno de las Cámaras' (SSTC 99/1987, FJ 1, y $57 / 1989$, FJ 2.c). El procedimiento del art. 74, no puede entenderse vulnerado, e segundo lugar.

(Rodríguez-Zapata Pérez): Se considera excesiva el celo de la STC en la preservación de las competencias de las Cámaras. La Sentencia opta por la strict construction con una interpretación pegada a la letra del texto constitucional. Esa interpretación es muy rigurosa frente el Poder ejecutivo, al que veda constitucionalmente el decreto-ley y la aplicación provisional de los tratados. También lo es frente a las mismas Cortes Generales, cuya potestad legislativa se comprime, al excluir la Ley ordinaria de entre las fuentes del Derecho idóneas para expresar una autorización parlamentaria, prohibiendo uno de los contenidos típicos de la Ley en todos los ordenamientos. El mantenimiento de ese rigor en situaciones de gravedad para España podría abocar a la alternativa peligrosa del incumplimiento constitucional o de la asfixia de nuestra acción exterior. El disentimiento afecta a aspectos esenciales de la Sentencia de la mayoría, en los que se acentúa desproporcionadamente ese garantismo parlamentario al que he hecho referencia. Se estima que se debieron desestimar los dos recursos acumulados. Asimismo se discrepa de que el uso del decreto ley en este caso no fuera aceptable. Una interpretación sistemática de la Norma Fundamental permite admitir que los decretos-leyes son una fuente del Derecho utilizable para prestar el consentimiento del Estado en circunstancias de extraordinaria y urgente necesidad. 


\section{Sentencia 189/2005, de 7 de julio (BOE de 5 de agosto). Ponente: Delgado Barrio (Recurso de inconstitucionalidad).}

Preceptos constitucionales: $31 ; 86$.

otros:

Objeto: artículos. 4, 5, 6, 7, 8, 9, 10, 11, 12, 13, 14, disposición adicional segunda y disposición final primera, párrafo tercero, del Real Decreto-ley 7/1996, de 7 de junio, sobre medidas urgentes de carácter fiscal y de fomento y liberalización de la actividad económica.

Materias: Ámbito material del decreto ley en materia tributaria. Materias vedadas a su regulación.

Se aduce vulneración del art. 86.1 CE, en relación con el art. 31.1 CE. Descritas sucintamente las modificaciones que mediante esos preceptos del RD1 impugnado se introducen en el ordenamiento tributario, se apresta el TC a considerar que no priva de objeto al presente recurso, el hecho de las algunas de las normas modificadas por el RD-l hayan sido derogadas o, posteriormente, modificadas. Al tratarse de una modificación del ordenamiento jurídico operada por un Decreto-ley es función esencial de esta jurisdicción garantizar 'la primacía de la Constitución' (art. 27.1 LOTC) y asegurar en todo momento, sin solución de continuidad, el correcto funcionamiento del sistema de producción normativa preconizado por la Norma fundamental, depurando y expulsando del ordenamiento las normas impugnadas que se aparten de dicho sistema, con independencia de que se encuentren o no en vigor cuando se declara su inconstitucionalidad. Es la pureza misma del ordenamiento jurídico la que se ventila en esta sede jurisdiccional, y ello ha de decidirse en términos de validez o invalidez ex origine de las normas impugnadas, sin atender a su vigencia o derogación en el momento en que se pronuncia el fallo constitucional (SSTC 60/1986, FJ 1, 137/2003 FJ 2, y $108 / 2004, \mathrm{FJ} 4)$, en la medida en que se trata de velar por el recto ejercicio de la potestad de emitir Decretos-leyes, dentro del marco constitucional (STC 111/1983, FJ 3; y 137/2003, FJ 2, y 108/2004, FJ 4). No comparte las quejas de los recurrentes el Abogado del Estado, que sostiene que el Real Decreto-ley 7/1996 no incurre en ninguna de las vulneraciones que se le imputan. En efecto, en primer lugar, a su juicio, el citado Real Decreto-ley cumple con el presupuesto habilitante que legitima su uso dado que existió una situación de "extraordinaria y urgente necesidad" que exigía la inmediata adopción de determinadas medidas de alcance económico, como era, respecto de la reducción por adquisición mortis causa de empresas familiares en el Impuesto sobre Sucesiones, el deseo de reactivar la economía potenciando el desarrollo de tales empresas; con relación a la actualización de balances en los Impuestos sobre Sociedades y sobre la Renta de las Personas Físicas, permi- 
tir a las empresas conocer sus costes reales de producción, determinando más exactamente sus beneficios y potenciando su capacidad de acceso al mercado de capitales y, finalmente, con referencia al nuevo régimen tributario de los incrementos y disminuciones patrimoniales en el impuesto sobre la renta de las personas físicas, el relanzamiento de la economía liberando la cautividad de las inversiones. En suma, a juicio del Abogado del Estado, explicitadas por el Gobierno las razones para la utilización de este instrumento legislativo, ningún rechazo cabe hacer desde esta primera perspectiva del recurso. Se comienza trayendo en su apoyo el TC la doctrina en torno al presupuesto habilitante de la extraordinaria y urgente necesidad exigido por el art. 86.1 CE (SSTC 182/1997, 11/2002, y 137/2003). En ellas, tras reconocer el peso que en la apreciación de la extraordinaria y urgente necesidad ha de concederse al juicio puramente político de los órganos a los que incumbe la dirección del Estado, se declaró que la necesaria conexión entre la facultad legislativa excepcional y la existencia del presupuesto habilitante conduce a que el concepto de extraordinaria y urgente necesidad que se contiene en la Constitución no sea, en modo alguno, una cláusula o expresión vacía de significado dentro de la cual el lógico margen de apreciación política del Gobierno se mueva libremente sin restricción alguna, sino, por el contrario, la constatación de un límite jurídico a la actuación mediante decretos-leyes. En atención a esa consideración estima el TC que es función propia del mismo el aseguramiento de estos limites, la garantía de que en el ejercicio de esta facultad, como de cualquier otra, los poderes se mueven dentro del marco trazado por la Constitución, de forma que el Tribunal Constitucional podrá, en supuestos de uso abusivo o arbitrario, rechazar la definición que los órganos políticos hagan de una situación determinaday, en consecuencia, declarar la inconstitucionalidad de un Decreto-ley por inexistencia del presupuesto habilitante por invasión de las facultades reservadas a las Cortes Generales por la Constitución (SSTC 11/2002 FJ 4; 137/2003, FJ 3). En coherencia con la doctrina expuesta, el TC recuerda que no estimó contraria al art. 86.1 CE la apreciación de la urgencia hecha por el Gobierno en casos de modificaciones tributarias que afectaban a las haciendas locales (STC 6/1983,), de situación de riesgo de desestabilización del orden financiero (STC 111/1983), de adopción de planes de reconversión industrial (SSTC 29/1986), de medidas de reforma administrativa adoptadas tras la llegada al poder de un nuevo Gobierno (STC 60/1986), de modificaciones normativas en relación con la concesión de autorizaciones para instalación o traslado de empresas (STC 23/1993), de medidas tributarias de saneamiento del déficit público (STC 182/1997) o, en fin, de necesidad de estimular el mercado del automóvil (STC 137/2003). Como es fácil comprobar en todas estas Sentencias, los Decretos-leyes enjuiciados en ellas afectaban a lo que la STC 23/1993, FJ 5, denominó coyunturas económicas problemáticas para cuyo tratamiento el Decreto-ley representa un instrumento constitucionalmente lícito que no es otro que subvenir a situaciones concretas de los objetivos gubernamentales que por razones dificiles de prever requieran una acción normativa inmediata en un plazo más breve que el requerido por la vía normal o por el 
procedimiento de urgencia para la tramitación parlamentaria de las leyes" (SSTC 6/1983 FJ 5; 11/2002, FJ 4; 137/2003, FJ 3). No olvida, sin embargo el TC que asimismo tiene afirmado que es claro que el ejercicio de la potestad de control que compete a este Tribunal implica que la definición por los órganos políticos de una situación de 'extraordinaria y urgente necesidad' sea explícita y razonada, y que exista una conexión de sentido o relación de adecuación entre la situación definida que constituye el presupuesto habilitante y las medidas que en el Decreto-ley se adoptan (STC 29/1982, de 31 de mayo, FJ 3), de manera que estas últimas guarden una relación directa o de congruencia con la situación que se trata de afrontar (STC 182/1997, FJ 3). El examen de la concurrencia del citado presupuesto habilitante de la extraordinaria y urgente necesidad siempre se ha de llevar a cabo mediante la valoración conjunta de todos aquellos factores que determinaron al Gobierno a dictar la disposición legal excepcional y que son, básicamente, los que quedan reflejados en la exposición de motivos de la norma, a lo largo del debate parlamentario de convalidación, y en el propio expediente de elaboración de la misma (SSTC 29/1982, FJ 4; 182/1997, FJ 4; 11/2002, FJ 4; y 137/2003, FJ 3 ), debiendo siempre tenerse presentes las situaciones concretas y los objetivos gubernamentales que han dado lugar a la aprobación de cada uno de los Decretos-leyes enjuiciados (SSTC 6/1983, FJ 5; 182/1997, FJ 3; 11/2002, FJ 4; 137/2003, FJ 3). De conformidad con esta doctrina pasa a analizar el TC si en las modificaciones introducidas mediante el RD-l impugnado, concurre el presupuesto habilitante de la extraordinaria y urgente necesidad exigido por el art. 86.1 CE, a efectos de determinar la validez constitucional de su regulación. Para controlar la concurrencia de ese presupuesto habilitante es preciso analizar dos elementos: en primer lugar, los motivos que hayan sido explicitados de una forma razonada (STC 29/1982, FJ 3; 111/1983, FJ 5; 182/1997, FJ 3; y 137/2003, FJ 4) y, en segundo lugar, la existencia de una necesaria conexión entre la situación de urgencia definida y la medida concreta adoptada para subvenir a la misma (STC 29/1982, FJ 3; 182/1997, FJ 3; y 137/2003, FJ 4). Para el análisis de los citados motivos, se parte de un análisis de la Exposición de Motivos del RD-l: en la misma se señala, con carácter general, que el Real Decreto-ley se refiere a dos grandes grupos de medidas: el primero, aborda las cuestiones sobre fomento del empleo y beneficios fiscales en la sucesión de empresas familiares y viviendas habituales; medidas sobre actualización de balances de las empresas y medidas sobre tributación del ahorro en el impuesto sobre la renta de las personas físicas; el segundo, se refiere a un conjunto de medidas de fomento y de liberalización de la actividad económica. El primer grupo de medidas persigue aliviar el coste fiscal derivado de la transmisión mortis causa de las empresas familiares (en su forma de empresa individual o de participaciones) y de la vivienda habitual, cuando dicha transmisión se efectuase a favor de ciertas personas allegadas al fallecido. Con relación a la actualización de balances, se señala que, el escenario económico actual y el hecho de haber transcurrido más de doce años desde la última actualización autorizada, considerando además la reciente entrada en vigor de una Ley del impuesto sobre sociedades, justifican plenamente la norma de actualización contenida en el presente Real Decreto-ley, que permi- 
tirá, entre otras ventajas, a nuestras empresas conocer sus costes reales de producción, determinar más exactamente su beneficio y potenciar la financiación interna de las mismas elevando, por tanto, su capacidad de acceso al mercado de capitales", estableciendo además un gravamen único sobre el saldo de la cuenta de actualización del 3 por 100 con el objetivo de garantizar el adecuado control de la operación de actualización. Por lo que se refiere a las modificaciones en materia de tributación del ahorro, se justifican advirtiendo que el sistema diseñado por la Ley 18/1991, de 6 de junio, se caracterizaba porque la determinación del importe sometido a gravamen de los incrementos y disminuciones de patrimonio, consistía en el establecimiento de unos porcentajes reductores, de forma tal que, transcurrido un determinado período de tiempo -que variaba en función de la naturaleza del elemento-, los incrementos y disminuciones quedaban no sujetos. Este esquema cuenta con dos inconvenientes esenciales: de una parte, reduce tanto los incrementos como las disminuciones de patrimonio, con lo cual produce un efecto fiscal contrario a la lógica económica, pues no sólo desconoce el efecto de la inflación, sino que también reduce fiscalmente las pérdidas; y de otra, la existencia de un horizonte temporal fomenta el estancamiento de las inversiones, dado que existe un gran incentivo fiscal para mantener la inversión hasta que transcurre el plazo en que se alcanza la no sujeción de los incrementos. Por estas razones, el Gobierno considera de urgente necesidad para el relanzamiento de nuestra economía, el remover este obstáculo fiscal, liberando de esta cautividad a muchas inversiones, sin que desaparezcan, por otra parte, los incentivos que a la inversión a largo plazo supone el diferimiento de gravamen y la garantía de un tipo fijo. Por lo que se refiere al trámite de convalidación, como segundo aspecto del control del presupuesto habilitante del art. 86.1 CE, senalará el TC, que el Gobierno había apreciado urgencia en la situación económica española por varias razones: en primer lugar, la economía española lleva tres trimestres en un proceso de ralentización del crecimiento que requería sin duda antes del 7 de junio una respuesta inmediata y amplia por parte de los responsables políticos; en segundo lugar, una pérdida de potencial de crecimiento en la economía española; en tercer lugar, la confianza de los consumidores y de los mercados y, por último, los esfuerzos que deben hacer la sociedad española y el Gobierno para consolidar su posición en la tercera fase de la Unión Económica y Monetaria ... para conseguir que la economía española esté en condiciones de cumplir los requisitos nominales de convergencia. Determinadas las razones de la urgencia expresadas por el Gobierno tanto en la exposición de motivos de la norma cuestionada, como en el debate parlamentario de convalidación, el segundo elemento a analizar por el TC en el control del presupuesto habilitante es la conexión entre la situación de urgencia definida y la medida concreta adoptada para afrontar la misma. A estos efectos, proyecta el análisis sobre las medidas adoptadas por el Gobierno para hacer frente a esa situación de ralentización económica y de necesidad de cumplimiento de los requisitos de convergencia, medidas que se concretan en las disposiciones impugnadas; a estos efectos se traen a colación por el TC las razones aducidas en defensa de las medidas impugnadas: el art. 4 establece una reducción en la base correspondiente a la transmisión de la empresa familiar y de la vivienda habitual, con el 
objeto de eliminar el obstáculo que representa la carga tributaria para mantener el negocio y la vivienda familiar cuando fallece el propietario; el art. 5, que se refiere al fomento, ahorro y capitalización de las empresas a través de la actualización de balances es una medida voluntaria que contribuye sin duda, a elevar los niveles de capitalización y permite la creación de fondos de amortización en cuantía suficiente para reponer con fondos propios los activos amortizados, permitiendo que las empresas puedan revalorizar a precios reales sus activos aumentando su capacidad de crédito; y, finalmente, que los arts. 7 a 14 se justifican en que el sistema anterior que establecía una serie de coeficientes reductores que llegaban hasta la total exención del impuesto de plusvalías transcurridos 10, 15 ó 20 años, según los activos, producía un efecto de estancamiento de las inversiones con una situación de cautividad para los inversores respecto a sus primeras decisiones, de manera que existía una prima fiscal para la inmovilidad del ahorro que el Gobierno considera esencialmente negativa, lo que suponía en el conjunto de la economía española que ... una parte esencial del sistema económico, que es el ahorro, se encontrara cautivo en situaciones en las que había una prima fiscal para su inmovilidad. A la vista de las razones señaladas, el TC concluye que se ha cumplido con el requisito de justificar la apreciación de la urgente y extraordinaria necesidad, en tanto que dicha urgencia viene claramente explicitada, tanto en la exposición de motivos de la norma impugnada como en los debates parlamentarios de convalidación. Sin que represente un óbice para alcanzar esta conclusión el hecho de que algunas de las medidas hayan diferido su entrada en vigor hasta unos meses después de su aprobación, porque no cabe duda de que la existencia misma de esa medida permite al obligado tributario de forma instantánea adoptar decisiones económicas que provocarán el relanzamiento de la economía: el conocimiento, a ciencia cierta, del régimen fiscal de próxima aplicación, permite desarrollar ya actuaciones con una eficacia económica inmediata, lo que en este caso, habida cuenta de la finalidad perseguida, resulta bastante para justificar el cauce normativo utilizado. El segundo test de aplicación consistirá en comprobar la conexión entre la urgencia explicitada y las concretas medidas adoptadas. Las medidas aprobadas se manifiestan como idóneas para la consecución de la finalidad pretendida. En efecto, si la reducción en la base imponible del impuesto sobre sucesiones pretende garantizar la continuidad en el ejercicio de actividades empresariales por grupos familiares, impidiendo con ello la destrucción de empleo, tanto la actualización de balances (que permite la revalorización de las empresas y, por ende, una mayor posibilidad de endeudamiento de las mismas con el fin de practicar nuevas inversiones), como la modificación de la tributación de las plusvalías en el impuesto sobre la renta de las personas físicas, son medidas potencialmente favorables a una activación del mercado de capitales, al dirigirse a liberar el dinero y a estimular su movilidad, lo que a su vez puede incidir favorablemente en la recuperación de la actividad económica a la que se aspiraba para el cumplimiento de los criterios de convergencia. A la vista de las circunstancias y las razones expuestas concluirá el TC que es apreciable una situación de extraordinaria y urgente ne- 
cesidad que justificaba la inclusión en el Real Decreto-ley impugnado de las medidas aquí analizadas. Acerca del carácter provisional o definitivo de las medidas adoptadas en el meritado RD-l, el TC advierte que ya tiene declarado cómo en la STC 111/1983 (FJ 3) estableció nuestra jurisprudencia una conexión entre el carácter provisional del Decreto-ley (art. 86.1 CE) y la necesidad de que sea convalidado o derogado en el plazo de treinta días por el Congreso de los Diputados (art. 86.2 CE), de forma tal que, una vez que se ha producido esa convalidación, 'cede su carácter de provisionalidad' (STC 178/2004, FJ 6). A su vez, estimará que ningún dato positivo constitucional permite afirmar que el carácter provisional del Decreto-ley se refiera necesariamente al alcance temporal de la norma que con esa forma jurídica se apruebe, sin perjuicio de que dicho alcance pueda ser considerado de algún modo para valorar la concurrencia del presupuesto de su extraordinaria y urgente necesidad; en este caso concreto, la permanencia de las normas discutidas no tiene virtualidad bastante para alterar la conclusión ya sentada respecto de la concurrencia del presupuesto habilitante exigido por el el art. 86.1 CE. El siguiente aspecto de la cuestión afrontado por el TC, estriba en determinar si el contenido de 1 norma debatida se atempera con las exigencias del art. 86 por cuanto son el objeto del art. $31 \mathrm{CE}$ : al establecer, respectivamente un beneficio fiscal y un nuevo tributo, rebasan los límites que impone el art. 86.1 CE, en la medida en que invaden el ámbito material reservado a la ley conforme a los arts. 31.3 y 133.1 CE, de una parte; de otra, al prever un nuevo régimen para los incrementos y disminuciones patrimoniales, estarían afectando al núcleo esencial del deber de contribuir previsto en el art. 31.1 CE, en tanto que provocarían una modificación del reparto de la carga tributaria en un tributo como el IRPF que es fundamental para hacer efectivo el citado deber. Subrayará el TC su doctrina, centrada en las SSTC 182/1997, 137/2003 y $108 / 2004$, de que la materia tributaria esté sujeta al principio de reserva de ley y de que dicha reserva tenga carácter relativo y no absoluto por lo que no se deriva necesariamente que se encuentre excluida del ámbito de regulación del Decreto-ley, que podrá penetrar en la materia tributaria siempre que se den los requisitos constitucionales del presupuesto habilitante y no 'afecte', en el sentido constitucional del término, a las materias excluidas", límite material "que no viene señalado por la reserva de ley. El TC deberá atender, al interpretar el límite material del art. $86.1 \mathrm{CE}$, no... al modo cómo se manifiesta el principio de reserva de ley en una determinada materia, la tributaria en este caso (si tiene carácter absoluto o relativo y qué aspectos de dicha materia se encuentran amparados o no por dicha reserva), sino más bien al examen de si ha existido 'afectación' por el Decreto-ley de un derecho, deber o libertad regulado en el Título I de la Constitución. Lo que exigirá tener en cuenta la configuración constitucional del derecho o deber afectado en cada caso y la naturaleza y alcance de la concreta regulación de que se trate (FFJJ 8, 6 y 7, respectivamente). Esta doctrina permite al TC rechazar sin mayor dilación la alegada vulneración del art. 86.1 CE por la sola circunstancia de que dichos preceptos pudieran incidir sobre una materia que, conforme a los arts. 31.3 y 133.1, ambos CE, estuviera reservada a la ley, dado que lo relevante a estos efectos 
no es si el Decreto-ley impugnado invade o no materias reservadas a la ley, sino si afecta a alguna de las materias que, conforme al Texto Constitucional, le están vedadas. Como ya se señaló en las SSTC 182/1997, 137/2003 y 108/2004, en la sección segunda del capítulo II del título I de la Constitución, bajo la rúbrica De los derechos y deberes de los ciudadanos, figura el art. 31.1 $\mathrm{CE}$, precepto que establece un auténtico mandato jurídico, fuente de derechos y obligaciones, del que se deriva un deber constitucional para los ciudadanos de contribuir, a través de los impuestos, al sostenimiento o financiación de los gastos públi$\cos$ (FJ 6, en las dos primeras SSTC citadas; FJ 7, en la tercera). Por ello el TC desde la STC 6/1983 -cuya doctrina fue seguida por las SSTC 41/1983; $51 / 1993$; 182/1997, 137/2003 y 108/2004, de 30 de junio- ha incluido entre los deberes cuya afectación está vedada al Decreto-ley, el deber de contribuir al sostenimiento de los gastos públicos que enuncia el art. 31.1 CE. En relación con los límites materiales de la utilización del Decreto-ley, se ha venido manteniendo siempre una posición equilibrada que evite las concepciones extremas, la cláusula restrictiva del art. 86.1 de la Constitución ('no podrán afectar') debe ser entendida de modo tal que ni reduzca a la nada el Decreto-ley, que es un instrumento normativo previsto por la Constitución ... ni permita que por Decreto-ley se regule el régimen general de los derechos, deberes y libertades del título I (SSTC 111/1983, FJ 8; 60/1986, FJ 4; 182/1997, FJ 6; 137/2003, FJ 6; 108/2004, FJ 7). Posición que le ha llevado a concluir que el Decreto-ley no puede alterar ni el régimen general ni los elementos esenciales del deber de contribuir", lo que exige precisar cómo se encuentra definido dicho deber en la Norma fundamental, concretamente en su art. 31.1; y es que, como señalamos en la STC 111/1983, comprobar cuándo el Decreto-ley 'afecta' a un derecho, deber o libertad 'exige también que se tenga muy en cuenta la configuración constitucional del derecho en este caso, deber- afectado en cada caso' (FJ 8) (por todas, STC 108/2004, FJ 7). Trayendo a colación lo que ya se dijo en las SSTC 182/1997, 137/2003 y 108/2004, el art. 31.1 CE conecta el citado deber de contribuir con el criterio de la capacidad económica (con el contenido que a este principio de justicia material se ha dado, fundamentalmente, en las SSTC 27/1981, 37/1987, 150/1990, 221/1992 y 134/1996), y lo relaciona, a su vez, claramente, no con cualquier figura tributaria en particular, sino con el conjunto del sistema tributario. El art. $31.1 \mathrm{CE}$, en efecto, dijimos tempranamente en la STC 27/1981, 'al obligar a todos al sostenimiento de los gastos públicos, ciñe esta obligación en unas fronteras precisas: la de la capacidad económica de cada uno y la del establecimiento, conservación y mejora de un sistema tributario justo inspirado en los principios de igualdad y progresividad' (FJ 4). Conforme a la propia literalidad del art. 31.1 CE queda claro, pues, que el Decreto-ley no podrá alterar ni el régimen general ni aquellos elementos esenciales de los tributos que inciden en la determinación de la carga tributaria, afectando asi al deber general de los ciudadanos de contribuir al sostenimiento de los gastos públicos de acuerdo con su riqueza mediante un sistema tributario justo" (FJ 7). De manera que vulnerará el art. $86 \mathrm{CE}$ cualquier intervención o innovación normativa que, por su entidad cualitativa o cuantitativa, altere sensiblemente la posición del obligado a contribuir según su capacidad económica en el conjunto del sistema tributario (FFJJ 6 y 7 , res- 
pectivamente); en conclusión, no queda absolutamente impedida la utilización del Decreto-ley en materia tributaria, cuando concurre el supuesto habilitante, como instrumento normativo del Gobierno al servicio de los objetivos de la política económica. Ahora bien, será preciso tener en cuenta en cada caso en qué tributo concreto incide el Decreto-ley (constatando su naturaleza, estructura y la función que cumple dentro del conjunto del sistema tributario, asi como el grado o medida en que interviene el principio de capacidad económica), qué elementos del mismo-esenciales o noresultan alterados por este excepcional modo de producción normativa y, en fin, cuál es la naturaleza y alcance de la concreta regulación de que se trate (FFJJ 6 y 7). A la luz de esta doctrina, pasará el TC a examinar si los preceptos debatidos vulneran el art. 86 CE. Siguiendo la STC 182/1997, la naturaleza del tributo sobre el que incide, es una pauta prioritaria del análisis, por lo que si en el asunto allí debatido -el IRPF-, no podía negarse que el aumento de su cuantía mediante el uso de dicho instrumento normativo había afectado sensiblemente al deber de los ciudadanos de contribuir al sostenimiento de los gastos públicos de acuerdo con su capacidad económica, tal y como éste se configura en el art. 31.1 CE (FJ 9). El IRPF es un impuesto de carácter directo, personal y subjetivo, que grava la renta global de las personas físicas de manera progresiva (SSTC 45/1989, FJ 2, 150/1990, FJ 5, y 214/1994, FJ 5), constituyendo uno de los pilares estructurales de nuestro sistema tributario y, por sus características ... cualquier alteración en sus elementos esenciales repercute inmediatamente sobre la cuantía o el modo de reparto de la carga tributaria que debe levantar la generalidad de los contribuyentes; al mismo tiempo, es sobre todo a través del impuesto sobre la renta de las personas físicas como se realiza la personalización del reparto de la carga fiscal en el sistema tributario según los criterios de capacidad económica, igualdad y progresividad, lo que lo convierte en una figura impositiva primordial para conseguir que nuestro sistema tributario cumpla los principios de justicia tributaria que impone el art. $31.1 \mathrm{CE}$, dada su estructura y su hecho imponible (STC 134/1996, FJ 6); en definitiva, es innegable que el impuesto sobre la renta de las personas físicas, por su carácter general y personal, y figura central de la imposición directa, constituye una de las piezas básicas de nuestro sistema tributario, siendo el tributo en el que el principio de capacidad económica y su correlato, el de igualdad y progresividad tributarias, encuentran una más cabal proyección, de manera que es, tal vez, el instrumento más idóneo para alcanzar los objetivos de redistribución de la renta (art. $131.1 \mathrm{CE}$ ) y de solidaridad (art. 138.1 CE) que la Constitución española propugna (STC 19/1987, FJ 4) y que dotan de contenido al Estado social y democrático de Derecho (art. $1.1 \mathrm{CE}$ ). Conforme a lo expuesto se concluye que los arts. 6 a 14, la disposición adicional segunda y, por consecuencia, la disposición final primera, párrafo tercero, alteran de forma sustancial, en el IRPF el régimen tributario aplicable a los incrementos y disminuciones patrimoniales. Estos preceptos han afectado a la esencia del deber de contribuir al sostenimiento de los gastos públicos que enuncia el art. 31.1 CE, pues al modificar el régimen tributario de los incrementos y disminuciones patrimoniales en un tributo que, como el IRPF constituye una de las piezas básicas de nuestro sistema tributario, se ha alterado el modo de reparto de la carga tributaria que debe levantar la generalidad de los 
contribuyentes, en unos términos que, conforme a la doctrina de este Tribunal (SSTC 182/1997, 137/2003, y 108/2004, ya citadas), están prohibidos por el art. 86.1 CE. No se alcanzará la misma conclusión respecto de los arts. 4 y 5 del Real Decreto-ley. En efecto, como hemos visto anteriormente, el art. 4 se limita a establecer una reducción en la base imponible del ISD exclusivamente en los supuestos de transmisión mortis causa de la empresa familiar y de la vivienda habitual del causante; este tributo no se configura como un tributo global sobre la renta o sobre el consumo, limitándose a gravar una manifestación concreta de capacidad económica, la que se pone de manifiesto con las adquisiciones lucrativas de bienes o derechos, razón por la cual no puede afirmarse que la modificación parcial de su base imponible para determinados sujetos pasivos repercuta sensiblemente en el criterio de reparto de la carga tributaria entre los contribuyentes; lo mismo puede decirse del art. 5 del Real Decreto-ley 7/1996, en la medida en que se limita a establecer una actualización de balances a cambio de una compensación del 3 por 100 del saldo acreedor de la cuenta reserva de revalorización, actualización a la que sólo pueden acogerse determinados sujetos pasivos de los impuestos sobre sociedades y sobre la renta de las personas físicas y que tiene carácter voluntario, tampoco puede concluirse que haya alterado de manera relevante la presión fiscal que deben soportar la generalidad de los contribuyentes. En último término y para precisar el alcance de la presente Sentencia deben declararse no susceptibles de ser revisadas como consecuencia de la nulidad que ahora declaramos no sólo aquellas situaciones decididas mediante Sentencia con fuerza de cosa juzgada (art. 40.1 LOTC), sino también por exigencia del principio constitucional de seguridad jurídica (art. 9.3 CE), las establecidas mediante actuaciones administrativas firmes.

\section{ORGANIZACIÓN TERRITORIAL DEL ESTADO}

\section{A. Comunidades Autónomas.}

B.2. Competencias.

\section{Sentencia 154/2005, de 9 de junio (BOE de 8 de julio). Ponente: Rodríguez Arribas (Conflictos positivos de competencia acumulados).}

Preceptos constitucionales: 104; 149.1.29

otros:

Objeto: Arts. $52.3 ; 54.5$ b); 55; 56; 58; 60; 65.1 y $3 ; 81.1$ c) y 2 ; y 86.2 del Reglamento de seguridad privada, aprobado por Real Decreto 2364/1994, de 9 de 
diciembre, y por los arts. $1 ; 2 ; 3 ; 9 ; 13 ; 14 ; 22 ;$ y 23, en relación con los correspondientes anexos, de la Orden del Ministerio de Justicia e Interior, de 7 de julio de 1995 .

Materias: Seguridad pública. Enseñanza. Competencias exclusivas del Estado. Competencias de la Comunidad Autónoma.

La Generalidad de Cataluña considera que los preceptos impugnados vulneran sus competencias en materia de seguridad pública, así como sus competencias en materia de enseñanza (arts. 13 y 15 EAC). El Abogado del Estado sostiene que todas las competencias ejecutivas en discusión se inscriben en el ámbito de la materia seguridad pública que el art. 149.1.29 CE reserva en exclusiva al Estado. La doble controversia planteada sólo se refiere a la titularidad de la competencia para ejercer las facultades ejecutivas previstas en los preceptos cuestionados; la Generalidad de Cataluña reconoce que la regulación de los términos que ordenan su respectivo ejercicio corresponde al Estado. Con carácter previo al análisis de los presentes conflictos positivos de competencias, debemos advertir que durante el curso de este proceso el Reglamento de seguridad privada ha sido modificado parcialmente por Real Decreto 1123/2001, de 9 de octubre, que da nueva redacción a los art. 56.2 y 58 del Reglamento de seguridad privada, aquí impugnados. La lectura de los nuevos preceptos pone de relieve que su contenido no altera la controversia que se nos suscita, pues la modificación normativa se refiere a detalles de la regulación sustantiva que no inciden en la resolución que se nos reclama y, sin embargo, mantiene las actuaciones administrativas en litigio, las cuales siguen estando atribuidas al Ministerio del Interior. En relación con la desaparecida norma objeto de la controversia recuerda el TC que partiendo de nuestra doctrina de que hay que huir de todo automatismo, siendo necesario atender a las circunstancias concurrentes en cada caso y, ante todo, a la pervivencia de la controversia competencial, esto es, a si la disputa sobre la titularidad competencial sigue o no viva entre las partes, debe deducirse que esto es lo que ha sucedido en este caso, ya que no se ha desistido del presente conflicto (STC 128/1999, FJ 4) y teniendo en cuenta que la nueva normativa plantea en gran medida los mismos problemas competenciales que el Reglamento sobre el que se traba el conflicto, la doctrina de este Tribunal avala la conclusión de la no desaparición del conflicto (STC 186/1999, F J 3, con cita de las SSTC 87/1993, 329/1993, 155/1996, y 147/1998) (STC 223/2000, FJ 3). Los conflictos planteados exigen partir de la materia en la que han de encuadrarse las actividades administrativas que se discuten. Dichas actuaciones se refieren a los requisitos de habilitación, formación y acreditación del personal de seguridad privada, a la obtención de dicha habilitación o a su pérdida, a la acreditación de los centros de formación y también a la prestación de servicios con armas y a la uniformidad, entre otros extremos. Ambas representaciones coinciden en reclamar la titularidad de las funciones ejecutivas controvertidas con funda- 
mento en sus respectivas competencias en materia de seguridad pública (arts. 149.1.29 CE y 13 EAC). Respecto de algunos artículos (art. 56.2 del Reglamento de seguridad privada y arts. 1, 2 y 3 de la Orden) la Generalidad de Cataluña aduce, además, su competencia en materia de enseñanza (art. 15 EAC). Las actuaciones administrativas tienen indudable conexión con el mantenimiento de la tranquilidad u orden ciudadano, que es en lo que consiste la seguridad pública (STC 33/1982), procede confirmar la incardinación de la reglamentación controvertida en la materia de seguridad pública; a este criterio conduce la propia definición legal de lo que se entiende por seguridad privada, que se concibe como la prestación por personas, físicas o jurídicas, privadas de servicio de vigilancia y seguridad de personas o bienes, que tendrán la consideración de actividades complementarias y subordinadas respecto a las de seguridad pública (art. 1 de la Ley 23/1992). Los preceptos del bloque de la constitucionalidad que delimitan la distribución de competencias en la materia de seguridad pública son el 149.1.29 CE que atribuye al Estado la competencia exclusiva en materia de seguridad pública, sin perjuicio de la posibilidad de creación de policías por las Comunidades Autónomas en la forma que se establezca en los respectivos Estatutos en el marco de lo que disponga una Ley Orgánica. Por su parte, el EAC establece la Generalidad podrá crear una Policía Autónoma en el marco del presente Estatuto y, en aquello que no esté específicamente regulado en el mismo, en el de la Ley Orgánica prevista en el art. 149.1.29 de la Constitución (art. 13.a EAC). La Ley Orgánica 2/1986 de fuerzas y cuerpos de seguridad (LOFCS), a la que se remite el art. 149.1.29 CE a fin de determinar el marco en el que los Estatutos de Autonomía pueden concretar la creación de policías propias por las respectivas Comunidades Autónomas. La disposición adicional cuarta de la Ley 23/1992 de seguridad privada no forma parte del bloque de la constitucionalidad (art. 28 LOTC). La doctrina del TC materia de seguridad pública, con el precedente de las SSTC 33/1982 y 117/1984, arranca al menos de la STC 104/1989, y está resumida, entre otras, en las más recientes SSTC 175/1999, 148/2000 y 235/2001. Según ya se avanzó en la citada STC 33/1982, FJ 3, se considera la seguridad pública actividad dirigida a la protección de personas y bienes y al mantenimiento de la tranquilidad y el orden ciudadano, incluye un conjunto plural y diversificado de actuaciones, distintas por su naturaleza y contenido, aunque orientadas a una misma finalidad tuitiva del bien jurídico asi definido. Dentro de este conjunto de actuaciones hay que situar, incluso de modo predominante, las específicas de las organizaciones instrumentales destinadas a este fin y, en especial, las que corresponden a los Cuerpos y Fuerzas de Seguridad, a que se refiere el art. 104 CE. Pero, por relevantes que sean, esas actividades policiales, en sentido estricto, o esos servicios policiales no agotan el ámbito material de lo que hay que entender por seguridad pública en cuanto que concepto delimitador de la competencia, aun sólo ejecutiva, de los poderes públicos. Otros aspectos y otras funciones distintas de los Cuerpos y Fuerzas de Seguridad, y atribuidas a otros órganos y autoridades administrativas ... componen, sin duda, aquel ámbito material (STC 104/1989, FJ 3). Lo que positivamente significa, que "la actividad policial es una parte de la materia más amplia de la seguridad pú- 
blica" (STC 175/1999, FJ 7). Y negativamente que "no puede sostenerse que cualquier regulación sobre las actividades relevantes para la seguridad ciudadana haya de quedar inscrita siempre y en todo caso en el ámbito de las funciones de los cuerpos de policía o asimiladas, pues es obvio que pueden regularse al respecto actuaciones administrativas que, sin dejar de responder a finalidades propias de la materia seguridad pública, no se incardinen en el ámbito de la actividad de dichos cuerpos" (STC 235/2001, de 13 de diciembre, FJ 8). Dicho en otros términos, no es posible realizar "una identificación absoluta entre la materia seguridad pública y las actuaciones que son propias de las Fuerzas y Cuerpos de Seguridad, es decir, no se reduce la normativa propia de la seguridad pública a regular las actuaciones específicas de la llamada Policía de seguridad" (STC 148/2000, de 1 de junio, FJ 6). La aludida no identificación absoluta entre la materia seguridad pública y el ámbito propio de la Fuerzas y Cuerpos de Seguridad exige delimitar con precisión este último ámbito ya que el TC ha declarado que es en orden a la organización de aquella policía autónoma y a los correspondientes servicios policiales no estatales respecto de lo que la Comunidad Autónoma ... ha asumido competencias en su Estatuto y no, en cambio, en relación con otras funciones de ejecución en materia de seguridad pública (STC 148/2000, FJ 7). Para delimitar el ámbito competencial de la Generalitat, convendrá realizar dos precisiones. La primera, es que el ámbito competencial correspondiente a la creación de policías autonómicas comporta no sólo una referencia orgánica sino también funcional (STC 175/1999, FJ 3), doble referencia que tiene no obstante muy concretado su ámbito: comprende sólo, además de la organización de la policía autónoma, el ejercicio dentro de su territorio autónomo de las funciones o servicios policiales no estatales, siendo, por tanto, el único espacio en el que la Generalidad de Cataluña puede desenvolver las competencias estatutarias relativas a su Policía propia (STC 235/2001, FJ 8). La segunda, consiste en señalar que el ámbito de la actividad estrictamente policial también incluye las potestades administrativas que le son complementarias o inherentes, aunque la identificación de estas últimas no es siempre sencilla. Será criterio del TC que no resulta fácil distinguir en ocasiones lo que debe entenderse por funciones o servicios policiales en sentido estricto ... de otros servicios y actividades de distinta naturaleza y semejante finalidad. También es verdad que, aunque lógicamente identificables por criterios tales como su contenido o la clase de órganos y autoridades a quienes se encomiendan, ciertas facultades administrativas no son separables, por su inherencia o complementariedad, de las tareas de prevención e investigación de hechos delictivos y persecución de los culpables, del mantenimiento del orden ciudadano y otras análogas que se atribuyen a los Cuerpos y Fuerzas de Seguridad (STC 104/1989, FJ 4). Así delimitado el ámbito propio de las Fuerzas y Cuerpos de Seguridad, no será inconveniente insistir en que dicho ámbito constituye el único espacio en el que la Generalidad de Cataluña pueda desenvolver las competencias relativas a su policía propia. Aplicando estos criterios, concluirá el TC que cuando las facultades administrativas en discusión no guarda[n] relación alguna con la actividad policial" la competencia para ejercerlas corresponde al Estado, habida cuenta 
que en tales supuestos "la existencia de [una] Policía autónoma no modifica la titularidad estatal de la competencia controvertida (STC 117/1984, FJ 5). En definitiva, será competencia de las CCAA que dispongan de policía de seguridad propia todas aquellas facultades que sean propias de las funciones o servicios policiales que hayan asumido con arreglo a lo dispuesto en los respectivos Estatutos y en la Ley Orgánica de Fuerzas y Cuerpos de Seguridad. Por el contrario, corresponderán al Estado las restantes potestades o facultades administrativas que no sean propias ni inherentes de las funciones o servicios policiales, a que se remite el art. 104.2 CE. La determinación de que la actividad controvertida sólo puede derivarse de la ponderación de su contenido y finalidad, de acuerdo con la doctrina del TC sobre los criterios de incardinación competencial (por todas, STC 197/1996, FJ 3), y no de la apreciación meramente mecánica de la relación que los órganos estatales a los que se haya atribuido su ejercicio puedan tener con la organización policial. Que el EAC no mencione expresamente la seguridad privada no puede significar que la Comunidad Autónoma carezca de toda competencia sobre el personal de seguridad. Será así, si las funciones ejecutivas en conflicto no guardan vinculación específica significativa con la competencia autonómica derivada de la creación de su propia policía de seguridad; si dicha vinculación específica existe, la conclusión habrá de ser lógicamente muy distinta. En suma, el canon de enjuiciamiento del TC se concreta en que en materia de seguridad pública al Estado le corresponden todas las potestades normativas y ejecutivas, salvo las que se deriven de la creación de policías autonómicas en el marco de la Ley Orgánica a la que se refiere el art. 149.1.29 CE. Esta última competencia incluye una doble dimensión orgánica y funcional respecto de los correspondientes servicios policiales y también la actividad administrativa que les sea inseparable por razón de inherencia o complementariedad. En relación con los preceptos impugnados del Reglamento de seguridad privada, aprobado por Real Decreto 2364/1994, convendrá distinguir dos bloques. (a) En primer lugar, el constituido por los arts. $52.3,54.5$ b) , 55, 56, 58, 60 y 65.1 y 3 . Todos ellos forman parte del título II (personal de seguridad), capítulo I (habilitación y formación) de dicho Reglamento; de la lectura de este capítulo I se deduce que el personal de seguridad privada debe obtener la correspondiente habilitación del Ministerio de Justicia e Interior. (b) En segundo lugar incidiremos en los arts. 81.1 c) y 2 y 86.2, que forman parte del capítulo II (funciones, deberes y responsabilidades) del mismo título II. Estos preceptos se refieren al régimen funcional del personal de seguridad privada relativo al empleo de armas u otras medidas de defensa en el servicio. Los preceptos del primer bloque regulan los requisitos que deben cumplir quienes pretendan obtener la habilitación como personal de seguridad privada en cualquiera de sus modalidades. Es criterio del TC que las actuaciones administrativas de carácter aplicativo que se impugnan tienen como finalidad, todas ellas, habilitar a determinadas personas para que puedan ejercer las funciones que son propias del personal de seguridad privada. Ha de tenerse también en cuenta tan- 
to el sentido o finalidad de los títulos competenciales, constitucionales y estatutarios como el carácter, sentido y finalidad de las disposiciones traídas al conflicto, es decir el contenido del precepto controvertido, delimitando así la regla aplicable al caso (STC 197/1996, FJ 3). Estos preceptos regulan actuaciones administrativas que no constituyen actividad propiamente policial, ni actuaciones administrativas inherentes a lo policial, actividades independientes y separadas de la propiamente policial, único ámbito sobre el que, en materia de seguridad pública, la Generalidad de Cataluña ha asumido competencias. En conclusión los arts. $52.3,54.5$ b) y 55 no vulneran las competencias de la Generalidad de Cataluña. Por lo que se refiere al segundo bloque de preceptos, desde la perspectiva de la posible vulneración por estos preceptos de las competencias de la Generalidad de Cataluña en materia de policía propia se descarta la existencia de esa vulneración por las mismas razones ya expuestas, se trata de facultades administrativas que, por su contenido y finalidad se encauzan a la regulación de la formación previa y del contenido de unas pruebas dirigidas a habilitar al personal de seguridad privada, lo que en absoluto guarda relación con las competencias de la Generalidad de Cataluña, sobre su propia policía. En relación con el art. art. 56.2 se ha de precisar si infringe las competencias de la Generalitat aquélla en materia de enseñanza, con apoyo en la invocada doctrina de la STC 122/1989, o si, por el contrario, tal vulneración no se produce. Este argumento debe ser rechazado, la atribución a órganos estatales de la autorización de centros en los que se imparten los módulos formativos y la correlativa expedición del diploma acreditativo constituye una regulación que, ni se inscribe en la materia de enseñanza, ni queda descalificada desde la perspectiva del orden constitucional de competencias por la doctrina de la STC 122/1989. En cuanto al encuadramiento de este art. 56.2 en la materia de enseñanza, no puede prosperar de acuerdo con la doctrina de la STC 122/1989: la competencia reservada al Estado por el citado art. 149.1.30 de la Constitución comprende como tal «la competencia para establecer los títulos correspondientes a cada nivel y ciclo educativo, en sus distintas modalidades, con valor habilitante tanto desde el punto de vista académico como para el ejercicio de las profesiones tituladas, es decir, aquellas cuyo ejercicio exige un título (ad ex: Graduado Escolar, Bachiller, Diplomado, Arquitecto Técnico o Ingeniero Técnico en la especialidad correspondiente, Licenciado, Arquitecto, Ingeniero, Doctor), asi como comprende también la competencia para expedir los títulos correspondientes y para homologar los que no sean expedidos por el Estado». $Y$ esta misma doctrina se reitera en la STC 82/1986. Es claro, por tanto, que la competencia que los órganos centrales del Estado tienen para regular las condiciones de obtención, expedición y homologación de los títulos profesionales se vincula directamente a la existencia de las llamadas profesiones tituladas, concepto éste que la propia Constitución utiliza en el art. 36, y que implícitamente admite, como parece obvio, que no todas las actividades laborales, los oficios o las profesiones en sentido lato son o constituyen profesiones tituladas. Como ha declarado este Tribunal en la STC 83/1984, tales profesiones tituladas existen cuando se condicionan determinadas actividades «a la posesión de concretos títulos académicos», y en un sentido todavía más 
preciso, la STC 42/1986 define las profesiones tituladas como aquellas "para cuyo ejercicio se requieren títulos, entendiendo por tales la posesión de estudios superiores y la ratificación de dichos estudios mediante la consecución del oportuno certificado o licencia». Según señalábamos en esta última Sentencia, corresponde al legislador, atendiendo a las exigencias del interés público y a los datos producidos por la vida social, determinar cuándo una profesión debe pasar a ser profesión titulada, y no es dudoso que, con arreglo al texto del art. 149.1.30 de la Constitución, es el legislador estatal quien ostenta esta competencia exclusiva (STC 122/1989, , FJ 3). De acuerdo con esta doctrina, se niega que la habilitación controvertida y las actuaciones formativas complementarias puedan incardinarse en la materia de enseñanza (SSTC 122/1989, FJ 2; 118/1996). En conclusión, los arts. 56, 58 y 60 no vulneran las competencias de la Generalidad. Por lo que se refiere al art. 56, se trata de una obligación que se impone al personal de seguridad que está en el ejercicio de sus funciones. El TC considera que la devolución de la tarjeta de identidad profesional y de la licencia y de la guía del arma son consecuencia de la pérdida de la habilitación por haberse producido algunas de las circunstancias que se regulan en el precedente art. 64.1. Esa pérdida de la habilitación sólo puede ser acordada por quien la otorgó, es decir, por el órgano estatal competente, lo que determina que la tarjeta de identidad, la licencia y la guía del arma sean entregadas también a los órganos estatales, dada la estrecha relación existente entre dicha documentación y la existencia o no de habilitación. En definitiva, no se aprecia vulneración de las competencias de la Generalidad en este punto. El análisis del apartado 3, hay que realizarlo de acuerdo con la doctrina contenida en la STC 175/1999, donde se enjuició si los libros-registro y otros sistemas alternativos de la documentación que estaban obligados a llevar determinados establecimientos debían ser puestos a disposición de los órganos policiales estatales o de la policía autónoma. En esta Sentencia se afirmó la competencia autonómica sobre dicho control, pues el dato de la caracterización de las funciones cuestionadas como propias de los servicios policiales determina de principio la inserción en el ámbito competencial de la Comunidad Autónoma, lo que conllevaba la apreciación de que lo significativo para precisar la Administración competente fuera el control que debe ejercerse sobre la actividad de unos establecimiento que están situados en el País Vasco (STC 175/1999, FJ 6). En este caso hay que aplicar la misma doctrina. La vulneración de la competencia autonómica que se ha apreciado en el primer inciso se extiende también a su segundo inciso, sin perjuicio del establecimiento de los necesarios mecanismos de coordinación y cooperación con el Estado en los que venimos insistiendo. En conclusión, el art. 65.3 vulnera las competencias de la Generalidad de Cataluña. Por lo que se refiere a los arts. 81.1 c) y 2 y 86.2 del Reglamento, hay que tener en cuenta que en la STC 32/1993 ya se examinó una controversia competencial que se concretaba en el alcance que pudiera tener la regulación atinente al armamento que pudiera emplear el Cuerpo de Agentes Rurales, indicando que la normativa vigente no puede ser otra que la establecida por el propio Estado, que es al que corresponde en exclusiva la de- 
cisión última sobre la tenencia y uso de armas (art. 149.1.26 CE) (STC 32/1993, FJ 3). Por consiguiente, la competencia para autorizar los servicios que los vigilantes de seguridad pueden prestar con armas bajo determinadas circunstancias corresponde a los órganos policiales de la Generalidad de Cataluña. Por tanto el art. 81.1 c) y 2 vulnera las competencias de la Generalidad de Cataluña. En cuanto al art. 86.2, el juicio ha de ser distinto. El mismo contiene una regulación de los medios de defensa que puedan portar los vigilantes de seguridad. Esta regulación que, ciertamente, no responde a la competencia estatal regulada en el art. 149.1.26 CE, no por ello deja de incluirse en el ámbito competencial reservado al Estado (art. 149.1.29 CE), pues incide directamente en el ámbito de la seguridad pública, sin afectar a las competencias de la Generalidad en materia de policía En suma el art. 86.2 no infringe las competencias de la Generalidad. Por lo que se refiere a la Orden de 7 de julio de 1995, examina el TC, en primer lugar, los arts. 1, 2 (en conexión con el anexo 2) y 3 . La impugnación debe ser rechazada con apoyo en la fundamentación expuesta en el FJ 8 b), al examinar el art. 56.2 del Reglamento de seguridad privada. En dicho fundamento jurídico se ha sentado que la autorización de centros de formación del personal de seguridad privada se incardina, desde la perspectiva del sistema constitucional y estatutario de distribución de competencias, en la materia seguridad pública, y que este encuadramiento determina la operatividad de la competencia ejecutiva del Estado en razón al contenido y finalidad perseguidos por estos preceptos, lo que impide atribuirles el carácter de complementariedad o inherencia respecto de lo estrictamente policial que determinaría la competencia de la Generalidad de Cataluña, pudiendo concluirse que los tres primeros artículos y anexos correspondientes de la Orden no conculcan las competencias de la Generalidad de Cataluña. Por lo que se refiere a los arts. 9, 13 (en conexión con el anexo 5) y 14, el TC matiza que los arts. 9 y 13 guardan conexión con los arts. 56.1 y 60 del Reglamento de seguridad privada, preceptos que no se han considerado inconstitucionales en el fundamento jurídico $8 \mathrm{~b}$ ) por tratarse de actuaciones administrativas cuyo contenido y finalidad no son policiales. Por lo tanto procede ahora reiterar el mismo criterio. Por tanto los arts. 9 y 13 y el anexo 5 no infringen las competencias de la Generalidad de Cataluña. Tampoco lo hacen los dos primeros párrafos del art. 14, que regulan las características de la cartilla profesional, su entrega y sellado de la primera hoja, atribuyendo estas facultades a órganos estatales, pues les resulta aplicable la misma doctrina que a los restantes preceptos de este bloque. Distinta ha de ser, no obstante, nuestra respuesta en cuanto a la competencia estatal para anotar también en la cartilla profesional las menciones honoríficas. La Generalidad de Cataluña impugna esta previsión, pues carece de sentido que siendo la Generalidad la competente para conceder las mencionadas distinciones no lo sea también para proceder a su oportuna anotación en la correspondiente cartilla profesional. Este argumento impugnatorio es atendido por el TC. En relación con los arts. 22 y 23, el primero no vulnera las competencias de la Generalidad 
ya que las funciones a que se refiere nada tienen que ver con las tareas policiales que están comprometidas en la garantía de la seguridad y el orden públicos, ni con las administrativas inherentes a las mismas, por lo que su atribución al Estado no lesiona tampoco las competencias autonómicas que derivan de la creación de su propia policía. Respecto al art. 23, se deben distinguir dos aspectos de su contenido. En cuanto a los dos primeros párrafos nada opone la Generalidad. La tacha se atribuye al tercer párrafo, que confiere al Gobernador Civil la autorización de la sustitución excepcional de la uniformidad ordinaria en determinados supuestos. Esa taca de inconstitucional tampoco es atendida por el TC pues la regulación no se refiere a una autorización excepcional para momentos o casos concretos, sino que tiene una dimensión de aplicabilidad general en los supuestos descritos por el precepto, que no afecta a la Generalidad en materia de policía.

VOTO PARTICULAR (García-Calvo y Montiel): Se discrepa del fallo estimatorio a que se ha llegado en esta Sentencia, en lo referente al pronunciamiento relativo al art. 81.1.c) y 2 del Reglamento de seguridad privada, teniendo en cuenta que en materia de "seguridad pública" el art. 149.1.29 CE atribuye al Estado la competencia exclusiva. Se trae en apoyo del Voto la STC 175/1999, en la citada Sentencia se afirmaba no basta únicamente la conexión de una determinada función con la materia seguridad pública para encuadrarla competencialmente en ésta sino que, además del dato positivo de esa posible conexión, que se daría en todos los casos de funciones policiales, es necesario el negativo de la inexistencia de vinculación específica con la competencia derivada de la creación de la policía autonómica, cuyo ámbito competencial no comporta sólo una referencia orgánica, sino también funcional. En esa misma Sentencia ya se dijo que el sistema de controles objeto de la controversia era competencia de la Comunidad Autónoma del País Vasco, precisamente porque la estructura de verificación y registro de establecimientos localizados en un ámbito territorial determinado del que entonces tratábamos no se encontraba incluido entre los supuestos reservados y, por tanto, el nivel o grado de homogeneidad requerido en la prestación del servicio no era equiparable al de aquellos. Por consiguiente, es criterio del disidente que todo lo referente a la utilización de armas por el personal de las empresas de seguridad privada forma parte de los supuestos reservados a los servicios policiales del Estado, puesto que dicha determinación, como indicaba en sus alegaciones el Abogado del Estado, forma parte de la competencia exclusiva atribuida al Estado por el art. 149.1.26 CE en materia de régimen de producción, comercio, tenencia y uso de armas. Esta competencia debe residenciarse en el Estado al que corresponde en exclusiva la decisión última sobre la tenencia y uso de armas (art. 149.1.26 CE) (STC 32/1993, de 1 de febrero, FJ 3). En conclusión, se estima por el autor del Voto que las anteriores consideraciones debían haber conducido a la conclusión de que el art. 81.1.c) y 2 del Reglamento de Seguridad Privada no vulneraba la competencias de la Generalidad de Cataluña y por lo que el conflicto, en este punto, debía haber sido desestimado. 


\title{
2. Sentencia 212/2005, de 21 de julio (BOE de 18 de agosto). Ponente: Ara- gón Reyes (Conflicto positivo de competencia).
}

\author{
Preceptos constitucionales: 149.1.1.; 149.1.30
}

otros:

Objeto: Orden de 1 de julio de 1996, del Ministerio de Educación y Cultura, por la que se conceden ayudas de educación especial para el curso 1996-1997.

Materias: Enseñanza: normativa básica del Estado; competencia autonómica para el desarrollo y ejecución de 1 competencia. Principio de instrumentalidad: competencia material y competencia financiera. Principio de igualdad en todo el territorio nacional e instrumentos para salvaguardar su implementación.

Se plantea conflicto positivo de competencia al entenderse por parte de la Generalitat que la Orden impugnada le impide el ejercicio de sus potestades normativas y de ejecución, que son propias de su competencia normativa plena en materia de enseñanza (art. 15 del Estatuto de Autonomía de Cataluña, en adelante EAC). Por su parte, el Abogado del Estado entiende que dicha infracción no se produce si dicha Orden se valora teniendo en cuenta el criterio adoptado por el Gobierno al aceptar parcialmente el requerimiento previo que, ex art. 63.1 LOTC, le dirigió la Generalidad de Cataluña. En los términos en que el Gobierno aceptó parcialmente el requerimiento autonómico, la Orden impugnada se sustenta en las competencias estatales reguladas en el art. 149.1.1 y 30 de la Constitución y permite que la Generalidad de Cataluña ejercite sus competencias de desarrollo normativo y de ejecución en materia de enseñanza. Para resolver este conflicto, se plantea el Tc dos cuestiones previas. De un lado, el hecho de que el Gobierno de la Nación haya aceptado parcialmente el requerimiento de incompetencia que con carácter previo al planteamiento del conflicto le formuló el Gobierno de la Generalidad de Cataluña. De otro, que la Orden impugnada limitaba sus efectos al curso 1996-1997, de modo que su eficacia se encuentra agotada al día de hoy. Por lo que se refiere a la primera cuestión, se reitera la doctrina de la STC 188/2001, FJ 2, donde se ponía de relieve que dicha aceptación parcial no afecta sustancialmente al curso del proceso cuando la Comunidad Autónoma considera no atendida su reclamación competencial. Por lo que se refiere a la segunda cuestión, al agotamiento de los efectos de la Orden impugnada como consecuencia de la limitación de los mismos al curso 1996-1997, se aprecia que en los cursos sucesivos se han convocado las ayudas a través de las correspondientes Órdenes, las cuales mantienen similares planteamientos de atribución competencial que la Orden traída al conflicto; por lo que procede que se reitere el criterio de que en los 
casos en que se producen modificaciones normativas e, incluso, derogaciones de las disposiciones objeto de conflicto 'hay que huir de todo automatismo, siendo necesario atender a las circunstancias concurrentes en cada caso, y, ante todo, a la pervivencia de la controversia competencial, esto es, a si la disputa sobre la titularidad competencial sigue o no viva entre las partes (por todas, STC 119/1986, 182/1988, 248/1988, 329/1993, 155/1996)' (STC 147/1998, FJ 3). Ya había precisado el TC que, en un procedimiento de naturaleza competencial, esa incidencia posterior no habría de llevar a la total desaparición sobrevenida de su objeto, máxime cuando las partes -como aqui ocurre-sostengan expresa o tácitamente sus pretensiones iniciales, pues la función de preservar los ámbitos respectivos de competencia, poniendo fin a una disputa todavía viva, no puede quedar automáticamente enervada por la, si así resultase ser, modificación de las disposiciones cuya adopción dio lugar al litigio (STC 182/1988, FJ 1). Sin olvidar que también se ha dicho que si la normativa en relación con la cual se trabó el conflicto no es simplemente derogada, sino parcialmente sustituida por otra que viene a plantear en esencia los mismos problemas competenciales, la doctrina del TC avala la conclusión de la no desaparición del objeto del conflicto (SSTC 87/1993, 329/1993 y 155/1996) (STC 128/1999 FJ 4, con cita de la STC 147/1998, FJ 5) (STC 188/2001, FJ 2). En conclusión, el presente conflicto positivo de competencia no ha experimentado una pérdida sobrevenida de su objeto. Se hace preciso ahora encuadrar la Orden controvertida en el sistema constitucional de distribución de competencias. Ambas representaciones procesales señalan que las ayudas de educación especial reguladas por la Orden impugnada tienen una conexión prioritaria con la materia de educación (enseñanza): Sostiene el TC que ha de tenerse en cuenta que en casos como el que nos ocupa, en que la norma cuestionada puede entenderse comprendida en más de una regla definidora de competencias, debe determinarse ... cuál de ellas es la prevalente, teniendo presente, junto con los definidos ámbitos competenciales, la razón o fin de la norma atributiva de competencias y el contenido del precepto cuestionado (STC 153/1985, FJ 3, con cita de la STC 49/1984). Igualmente, se habrá de tener en cuenta la tradicional doctrina de que la inclusión de una competencia genérica debe ceder ante la competencia especifica (SSTC 71/1982, F2 y 87/1989, FJ 3, entre otras) (STC 190/2000, FJ 4). Las distintas leyes orgánicas que han regulado la enseñanza en sus diversas modalidades y niveles han incidido en la necesidad de la existencia de un sistema de ayudas o subsidios para garantizar el acceso a aquélla. En la STC 188/2001, FJ 4, se examinó el articulado de dichas leyes orgánicas, poniendo de relieve la conexión existente entre dicho sistema de ayudas y subsidios y el derecho a la educación (art. $27 \mathrm{CE}$ ), concluyendo entonces que tanto la legislación orgánica como la normativa reglamentaria configuran las becas como un elemento nuclear del sistema educativo dirigido a hacer efectivo el derecho a la educación, permitiendo el acceso de todos los ciudadanos a la enseñanza en condiciones de igualdad a través de la compensación de las condiciones socioeconómicas desfavorables que pudieran existir entre ellos, lo que determina que los poderes públicos estén obligados a garantizar su existencia y real aplicación (STC 188/2001, FJ 4). La Ley Orgánica 10/2002, de 23 de diciembre, de calidad de la edu- 
cación, mantiene la relevancia antes señalada de las ayudas a la enseñanza. De esta la legislación se desprende que el sistema de becas constituye un instrumento esencial para hacer realidad el modelo de Estado social y democrático de derecho que nuestra Constitución impone (art. 1.1), determinando en consecuencia que los poderes públicos aseguren que la igualdad de los individuos sea real y efectiva (art. 9.2 CE). De este modo se garantizan también la dignidad de la persona y el libre desarrollo de la personalidad (art. 10.1 CE) que suponen la base de nuestro sistema de derechos fundamentales. No es otra, en definitiva, la finalidad buscada por el legislador orgánico. Lo reseñado hasta aquí, puesto en conexión con el artículo primero de la Orden de 1 de julio de 1996, objeto de este conflicto, pone de manifiesto que estas ayudas, aun teniendo una orientación asistencial, se conectan con mayor intensidad con la materia educativa, en la medida en que apoyan el acceso a la educación especial de quienes precisan la misma para cursar con normalidad aquellos niveles educativos. De las dos materias aducidas, debe prevalecer la de enseñanza. A tenor del TC el criterio para determinar cuál sea el título principal de incardinación competencial debe ser obtenido valorando la doctrina de la STC 188/2001, donde se enjuiciaron dos Órdenes del Ministerio de Educación y Ciencia que convocaban becas y ayudas al estudio de carácter general para estudios universitarios y medios. En dicha Sentencia, considerando que el art. 27.5 CE determina que todos los poderes públicos garantizan el derecho de todos a la educación mediante una programación general de la enseñanza, se indicó que tal garantía se configura como una obligación que la Constitución impone a los poderes públicos, sin predeterminación de las prestaciones o medidas que se hayan de emplear a tal fin, puesto que las becas o ayudas no vienen directamente exigidas por aquel precepto constitucional (FJ 5). Partiendo de este pronunciamiento se alcanzaron dos ideas: En primer lugar, que el legislador orgánico, al desarrollar el derecho a la educación art. 27 CE), ha considerado a las becas como un elemento central para la efectividad de tal derecho. $Y$, en segundo lugar, que dicho legislador orgánico no ha regulado el entero régimen jurídico de las becas, pues dicha configuración central se complementa con la normativa de rango reglamentario" (STC 188/2001, FJ 5). Es claro que el citado art. 4 de la LO 10/2002 responde a los dos criterios expuestos de nuestra doctrina. Mantiene el TC que no se puede dejar de tener en cuenta que en la STC 188/2001 (FFJJ 12 y 13) ya se señaló que el encuadramiento de estas ayudas no se materializa de modo principal en el art. 149.1.1 CE, sino en el art. 149.1.30 CE (FJ 6), de modo que ahora procederá remitirse a la doctrina allí contenida debiendo subrayar dos extremos. De una parte, a tenor de lo establecido en el FJ 12 de la STC 188/2001, el art. 149.1.1 CE no puede amparar los artículos de dicha Orden que atribuyen a los órganos centrales del Estado competencias de carácter ejecutivo, pues aquél precepto constitucional está constreñido al ámbito normativo. De otro, que, igualmente ocurre con el resto de la regulación material, ya que ni los estudios objeto de beca, ni tampoco las clases y cuantía de las ayudas pueden estimarse integrantes de ese contenido primario del mencionado derecho fundamental, pues debe distinguirse, de un lado, entre los ele- 
mentos generales conformadores del derecho a obtener una beca, amparables en el art. 149.1.1 CE y alcanzados por la legislación orgánica y, cumpliendo determinadas exigencias, por la reglamentaria general, y, de otro, los criterios de política educativa que instrumentan coyunturalmente su acceso al mismo (STC 188/2001, FJ 13). La regla competencial del art. 149.1.30 CE prevalece sobre la del art. 149.1.1 CE por su mayor especificidad. Mayor especificidad que se justifica diciendo que mientras que la regla 1 del art. 149.1 CE se proyecta de modo genérico sobre todos los derechos fundamentales, el art. 149.1.30 CE, lo hace, de modo específico, sobre el derecho a la educación. De aquí que sea esta última regla competencial la que, en primer término, resulta aplicable al caso que ahora examinamos, pues aparece plenamente justificado que dichas becas, configuradas por el legislador orgánico como un elemento central para la garantía del derecho a la educación, sin mayor precisión normativa, sean reguladas de modo complementario por la normativa básica que le está atribuida al Estado para garantizar, precisamente, ese derecho (STC 188/2001, FJ $6)$. Este criterio debe ser mantenido también ahora respecto de las ayudas de educación especial que se controvierten. Por lo que se refiere al Estado, le corresponde el establecimiento de las normas básicas para el desarrollo del art. 27 $C E$ (art. 149.1.30 CE), mientras que a la Generalidad de Cataluña le está atribuida la regulación y administración de la enseñanza en toda su extensión, niveles y grados, modalidades y especialidades, en el ámbito de sus competencias, sin perjuicio de lo dispuesto en el art. 27 de la Constitución y Leyes Orgánicas que, conforme al apartado 1 del art. 81 de la misma, lo desarrollen; de las facultades que atribuye al Estado el número 30 del apartado 1 del art. 149 de la Constitución y de la alta inspección necesaria para su cumplimiento y garantía (art. $15 \mathrm{EAC}$ ). Las ayudas reguladas por la Orden controvertida son subvenciones públicas que se ordenan para hacer efectivo el derecho de todos a la educación, apoyando las necesidades especiales de sus beneficiarios (artículo primero) y compensando las condiciones socioeconómicas de las familias que no alcanzan determinados niveles de renta y patrimonio (artículo segundo); en relación con aquéllas, el TC tiene establecido que abundante dotrina que puede ser recopilada con lo establecido en la STC 13/1992, doctrina que con posterioridad se ha reiterado frecuentemente. Como ya se hizo con anterioridad -STC 188/2001- procederá ahora hacer aplicación de la citada doctrina jurisprudencial, como ya se dejó dicho en la citada STC 188/2001, dos son los criterios aplicables: (a) El primero de ellos consiste en tener presente que en relación con las ayudas o subvenciones incorporadas a los Presupuestos Generales del Estado, hemos manifestado que no existe una competencia subvencional diferenciada resultante de la potestad financiera del Estado, o, lo que es lo mismo, que el Estado ... no dispone de un poder general para subvenciones (gasto público), entendido como poder libre o desvinculado del orden competencial (STC 13/1992, FFJJ 4 y 6). En los fundamentos jurídicos 7 y 8 de esa misma Sentencia hemos advertido que, cuando el Estado ostenta un título competencial genérico de intervención que se superpone a la competencia de las Comunidades Autónomas sobre una materia, aun si ésta se califica de exclusiva, o bien tiene competencia sobre las bases o la coordinación general de un sector o materia, correspondiendo a las Comunidades Autónomas las 
competencias de desarrollo normativo y de ejecución, puede consignar subvenciones de fomento en sus Presupuestos Generales, especificando su destino y regulando sus condiciones esenciales de otorgamiento hasta donde lo permita su competencia genérica, básica o de coordinación, pero siempre que deje un margen a las Comunidades Autónomas para concretar con mayor detalle la afectación o destino o, al menos, para desarrollar o complementar la regulación de las condiciones de otorgamiento de las ayudas y su tramitación y siempre que respete las competencias exclusivas de ejecución y gestión que corresponda a las Comunidades Autónomas, salvo que la naturaleza de la medida haga imprescindible la gestión directa y centralizada para asegurar su plena efectividad dentro de la ordenación básica del sector, para garantizar iguales posibilidades de obtención y disfrute por parte de sus potenciales destinatarios en todo el territorio nacional o, por último, cuando dicha centralización sea un medio necesario para evitar que se sobrepase la cuantía global de los fondos destinados a la subvención. En todo caso, la necesidad de la gestión centralizada debe aparecer razonablemente justificada o deducirse sin esfuerzo de la naturaleza y contenido de la medida de fomento de que se trate (STC 91/1992, de 11 de junio)" (STC 188/2001, FJ 7). (b) a ese criterio hay que añadir un segundo, el canon de enjuiciamiento expuesto debe ser completado con el que corresponde exigir, según nuestra doctrina, a las normas básicas estatales, con el fin de verificar después si ... [se] satisfacen los requisitos exigibles a dichas normas básicas" (STC 188/2001, FJ 7); en relación con éstos, ya se insistió en el FJ 8 STC 188/2001 en la doble dimensión formal y material que tiene que caracterizar a aquéllas. En concreto, con referencia especial a la STC 69/1988, se señaló que la dimensión formal se manifiesta a través de la inclusión de la norma básica en la Ley formal, lo que garantiza una determinación cierta y estable de los ámbitos de ordenación de las materias en las que concurren y se articulan las competencias básicas estatales y reglamentarias autonómicas. Si bien, por excepción, es asimismo admisible que el Gobierno pueda servirse de su potestad reglamentaria para regular algunos de los aspectos básicos de una materia mediante Decreto, cuando resulten, por la naturaleza de ésta, complemento necesario para garantizar el fin a que responde la competencia estatal sobre las bases. En estos casos, el carácter básico de la norma reglamentaria también debe explicitarse, aceptándose excepcionalmente que no sea así cuando ello se infiera indudablemente de su propio contenido. En lo concerniente a la dimensión material de las normas básicas, siempre hay que estar a la valoración concreta de la norma, apreciando si la misma contiene los criterios determinantes para la ordenación del segmento sustantivo de que se trate, criterios dotados, en principio, de una cierta estabilidad y que constituyen el mínimo común normativo de dicho segmento (STC 141/1993 FJ 3, entre otras). Aplicando esta doctrina, comienza el TC por analizar el cumplimiento de los requisitos formales de la normativa básica. La Ley Orgánica 10/2002, de calidad de la educación, regula en su art. 4 las becas y ayudas al estudio, y dicho artículo queda cubierto en su configuración como norma básica por la declaración expresa de su disposición final sexta. Por tanto, se produce la cobertura legal exigida por la doctrina del TC. Aún en relación con el carácter básico que en su perspectiva formal 
pueda atribuirse a la Orden impugnada en este proceso, habida cuenta de que la misma no explicita ese carácter básico, se reitera aquí lo dicho sobre las Órdenes de becas al estudio enjuiciadas en la STC 188/2001, esto es, que su naturaleza de norma básica puede resultar admisible excepcionalmente si tal carácter se desprende de modo inequívoco de su contenido, como ocurre efectivamente en este caso al tratarse de una regulación completa cuyo cumplimiento resulta inexcusable para la obtención de las ayudas (STC 188/2001, FJ 8). Procede ahora analizar el contenido material del articulado de la norma combatida con el fin de apreciar si el mismo puede ser calificado de básico también desde esta perspectiva y ser, por ello, de aplicación en Cataluña, como sostiene el Abogado del Estado, o si, por el contrario, hubiera vulnerado las competencias de la Generalidad por carecer, total o parcialmente, de dicha naturaleza básica. Los preceptos que regulan el objeto y los tipos de ayudas y subsidios (artículo primero), los requisitos exigidos para su obtención (artículo segundo), los niveles educativos en que pueden aplicarse (artículo tercero), las líneas de ayudas y su cuantía (artículo cuarto) y los elementos a valorar para su otorgamiento (artículo decimotercero), serán el objeto primero de la argumentación del TC. En su criterio hay que tener en cuenta que en la STC 13/1992, FJ 8 b) hemos declarado que la competencia del Estado para dictar normas básicas (en este caso, en desarrollo del art. 27 CE) le permite consignar subvenciones de fomento en sus presupuestos generales, especificando su destino y regulando sus condiciones esenciales de otorgamiento hasta donde lo permita su competencia genérica, básica o de coordinación, debiendo precisar ahora que, en relación con las becas, dichas condiciones esenciales de otorgamiento pueden alcanzar hasta donde sea imprescindible para garantizar el cumplimiento por los poderes públicos de sus deberes en esta materia (art. 149.1.30 CE), y resulte necesario para conseguir la finalidad deseada y garantizar una política educativa homogénea para todo el territorio nacional, sin desconocer las competencias normativas y de ejecución de las Comunidades Autónomas [STC 188/2001, FJ 10 a)]. A tenor de esta doctrina, ninguna tacha apreciamos en los preceptos de este bloque. Es obvio que la fijación del objeto de las ayudas y sus modalidades (ayudas individuales y subsidios para familias numerosas), establecido en el artículo primero, constituye el elemento esencial de la competencia básica del Estado, que puede determinar la finalidad y orientación de su política educativa en aras de la efectividad del art. 27 de la Constitución. Lo propio ocurre con los requisitos exigibles para su otorgamiento y con la cuantía de las diferentes líneas de ayuda (artículos segundo y cuarto), así como su posible aplicación en los diferentes niveles educativos (artículo tercero), pues se trata de aspectos que son elementos centrales de las condiciones de otorgamiento de las ayudas, cuyo carácter detallado resulta una exigencia de su percepción uniforme en todo el territorio nacional, garantizando un trato igualitario a sus beneficiarios, según ya se declaró en relación con las mismas las mismas cuestiones en la STC 188/2001, FJ 10. La misma valoración merecen los elementos que han de ser tenidos en consideración para la concesión de las ayudas que se contienen en el artículo decimotercero. Aunque sean criterios que detalle que 
han de tenerse en cuenta en el proceso de tramitación administrativa de las ayudas, los mismos se orientan a la finalidad antes señalada de garantizar igual trato a todos los solicitantes del territorio nacional constituyendo un complemento necesario de los requisitos regulados en el artículo segundo y satisfaciendo el principio básico de que se incluya en la competencia estatal el establecimiento de cuantos requisitos sean precisos para asegurar la igualdad en el acceso a las citadas becas y ayudas (art. 4.1, párrafo tercero de la Ley Orgánica 10/2002). Por lo que se refiere a los preceptos en los que se regulan la cumplimentación de solicitudes en determinados impresos (artículo quinto); presentación de las solicitudes en los centros educativos y admisión a trámite (artículo sexto); verificación de las solicitudes, subsanación de errores y justificación de la no acreditación de requisitos (artículos séptimo, octavo y noveno); remisión de las solicitudes a los órganos administrativos estatales y autonómicos y ordenación y clasificación por los mismos de las solicitudes (artículos décimo y undécimo); estudio y formulación de propuesta de concesión de la ayuda (artículo duodécimo); remisión de las propuestas a la Dirección General de Formación Profesional y Formación Educativa para la denegación o concesión de las ayudas (artículo decimocuarto); publicación de las solicitudes que han recibido la ayuda, otorgamiento de las mismas e interposición de recursos, correspondiendo su resolución al Secretario General de Educación (artículo decimoquinto); y autorización a la Dirección General de Formación Profesional y Promoción Educativa para el desarrollo y aplicación de la Orden (disposición final tercera), nos encontramos, en apreciación del TC ante una regulación a la que el Letrado de la Generalidad reprocha una doble tacha: de un lado la vulneración de las competencias normativas de la Generalidad; y, de otro, la centralización de buena parte del procedimiento de tramitación, pues sólo se admite la intervención de las Comunidades Autónomas en la fase de evaluación de solicitudes y de propuesta de resolución, reservando a órganos estatales las funciones esenciales de denegación y concesión de las ayudas, el otorgamiento o pago de las mismas y la resolución de los posibles recursos. En la STC 188/2001 ya se enjuició el mismo doble reproche, es decir, el relativo a la regulación procedimental y el concerniente a la ejecución administrativa centralizada. A tenor de esa doctrina, se puso de manifiesto que aunque la normativa reguladora del sistema de becas tienda a garantizar el acceso a las ayudas a quienes cumplan determinados requisitos, esencialmente de orden académico y económico, asegurando así que las limitaciones de renta no constituyan un obstáculo para el acceso a las enseñanzas correspondientes, lo cierto es que todo ello no debe impedir la gestión descentralizada de las ayudas y la atención a las peculiaridades territoriales. Nuestra doctrina ya ha apreciado que la garantía de la eficacia de la normativa estatal ha de cohonestarse con el respeto al principio de autonomía, de modo que, en tal sentido, las 'dificultades que pudieran existir ... no pueden ser alegadas para eludir competencias que constitucionalmente correspondan a una Comunidad Autónoma, pues en tal caso, bastaría que en el diseño de una legislación estatal reguladora de una matera se dificultara artificialmente su ejecución autonómica para justifi- 
car la negación o supresión de esa competencia (SSTC 106/1987, FJ 4)' (STC 186/1999, de 14 de octubre, FJ 10) (STC 188/2001, FJ 11). El TC considera que e este supuesto se debe mantener el mismo criterio, no sólo porque nos encontremos en un supuesto similar al entonces enjuiciado, sino, muy especialmente, porque la gestión autonómica de las ayudas ha sido prevista por el art. 4.3, primer párrafo, de la Ley Orgánica 10/2002, que dispone que $e l$ desarrollo, ejecución y control de los sistemas de becas y ayudas al estudio previstos en los apartados anteriores corresponde a las Comunidades Autónomas en sus respectivos ámbitos de competencia. Por lo que se refiere a los inconvenientes que pudieran derivarse de la gestión de las ayudas por las Comunidades Autónomas,ya quedó indicado que podrían obviarse mediante el establecimiento de sistemas de cooperación; así: Las posibles dificultades previas pueden salvarse mediante diversas técnicas. En primer lugar, mediante una planificación que determine ... el tipo de proyectos que deba ser objeto de la actuación estratégica. La información que al respecto posea el Estado, junto con la proveniente de las Comunidades Autónomas, permite alcanzar criterios objetivos para distribuir territorialmente los fondos presupuestarios, con lo cual no tienen por qué producirse quiebras relevantes en la garantía de alcanzarse las mismas posibilidades de obtención de la subvención en todo el territorio nacional. En segundo lugar, mediante el establecimiento de mecanismos de cooperación y coordinación, a través de los cuales puede garantizarse la eficacia de las medidas que constituyen el objeto del Plan. [E]l argumento del agotamiento de los fondos no resulta determinante, puesto que pueden arbitrarse sistemas de cooperación que posibiliten el desplazamiento de los fondos (STC 186/1999, FJ 10). Tampoco considerará el TC justificado el argumento de la necesidad de una lista única de solicitantes de beca para todo el territorio nacional. El empleo de dicha lista única se ha considerado necesario por el Abogado del Estado como garantía del principio de igualdad, a fin de evitar que posibles becarios con mejor derecho en determinada Comunidad Autónoma dejen de percibir la ayuda en beneficio de otros en una Comunidad diferente. Sin embargo esta posibilidad, que, de existir, sólo se daría en el último segmento de becarios de la lista única, puede ser obviada con facilidad, dejando sin distribuir entre las Comunidades Autónomas un porcentaje de los fondos, de modo que, mediante los oportunos instrumentos de colaboración y, específicamente, a través de mecanismos de coordinación (por todas, STC 32/1983, FJ 2), dichos fondos se canalicen hacia los becarios con mejor derecho con independencia de su localización territorial, o utilizando cualquier otra técnica que no implique la centralización del procedimiento de otorgamiento del sistema de becas, impidiendo la gestión autonómica de la normativa estatal básica" (STC 188/2001, FJ 11). En definitiva, como ya se dijo en la STC 188/2001, FJ 11 antes trascrito, para lograr la igualdad en esta materia puede dejarse sin distribuir un porcentaje de los fondos o utilizar cualquier otra técnica que no implique la centralización del procedimiento del otorgamiento de las becas, siendo necesario reiterar también la llamada a la cooperación y a la coordinación entre el Estado y las Comunidades Autónomas que ya se hizo en el citado fundamento jurídico. A través de dicha cooperación y coordina- 
ción, instrumentadas mediante los sistemas que se consideren procedentes, es como puede hacerse efectiva la igualdad de tratamiento en el acceso a las becas por los solicitantes de todo el territorio nacional, garantizando que ninguno de ellos resulte perjudicado en dicho acceso, de manera que se les asegure un trato igualitario con independencia del territorio en que se encuentren. En conclusión, la atribución a órganos estatales de funciones de tramitación administrativa de estas ayudas y subsidios, prevista en este segundo bloque de precepto, vulnera las competencias de la Generalidad en materia de enseñanza. En relación con la segunda tacha, relativa a la incompetencia estatal para regular la tramitación de las ayudas, pues dicha tramitación vaciaría la competencia normativa de la Generalidad de Cataluña, es objeción que ha se ser confirmada, pues la regulación de todos estos aspectos no constituyen normas básicas para el desarrollo del art. 27 CE, sino normas reguladoras del procedimiento de gestión de las ayudas que se inscribe en el ámbito de la competencia de la Generalidad en materia de enseñanza, y ya hemos declarado con reiteración que las normas procedimentales ratione materiae deben ser dictadas por las Comunidades Autónomas competentes en el correspondiente sector material, respetando las reglas del procedimiento administrativo común (por todas, STC 98/2001, de 5 de abril, FJ 8, con cita de la STC 227/1998, de 26 de noviembre, FJ 32). Por tanto, debe ser la Generalidad de Cataluña quien establezca el procedimiento de gestión, control y resolución de las solicitudes de beca que se presenten y determine los órganos competentes para ello (STC 188/2001, FJ 11). Finalmente, considerará el Tc que la DF tercera también vulnera las competencias de la Generalidad de Cataluña por un doble motivo: En primer lugar, porque la atribución a un órgano estatal de funciones aplicativas de la Orden que corresponden a la Generalidad de Cataluña, determina la infracción del orden constitucional de competencias; en segundo lugar, porque la previsión de que dicha Dirección General, en la dimensión normativa, pueda continuar desarrollando lo regulado en la Orden conlleva una infracción de la perspectiva formal de las normas básicas; ya tuvo el TC ocasión de decir que no resulta posible que las bases continúen siendo reformuladas de modo sucesivo a través de instrumentos normativos de rango inferior a la Ley y al Real Decreto" (aunque sin excluir la Orden Ministerial capaz de contener regulación básica en esta materia en supuestos muy excepcionales, como ya hemos manifestado más atrás); dicha reformulación sólo es aceptable a través de resoluciones administrativas "en la medida en que, simplemente, realizan la convocatoria anual y no incorporan prescripciones adicionales a las contenidas en las Órdenes Ministeriales respecto a las condiciones de obtención de las ayudas. [y, por ello, en esa sola medida] no contravienen tampoco el principio de no reformulación sucesiva de la normativa básica (STC 242/1999, , FFJJ 8 y 9). Por lo que, a sensu contrario, en este caso la disposición vulnera las competencias de la Generalidad al prever el desarrollo normativo de la Orden por aquella Dirección General. En razón a la doble tacha apreciada, todos los artículos de este segundo grupo vulneran las competencias de la Generalidad de Cataluña. En cuanto a los efectos del fallo, puesto que la Orden de 1 de julio de 1996 ha agotado todos sus efectos, de- 
bemos entender que la pretensión planteada por la Generalidad de Cataluña en este conflicto positivo de competencia se satisface mediante la sola declaración de las competencias que le corresponden.

VOTO PARTICULAR (Jiménez Sánchez): Se reitera el disentimiento que ya se explicitara en relación con la argumentación y fallo de la STC 188/2001. No resulta correcto, según el disidente, equiparar el singular sistema de asistencia o de complemento de la capacidad económica que suponen las becas o ayudas para el estudio a otras ayudas o subvenciones financieras encuadrables en el campo de las clásicas medidas de fomento de determinadas actividades de índole o naturaleza patrimonial. El título competencial primario o esencial que habilita para el establecimiento de una política de becas o ayudas al estudio, y para configurar la disciplina jurídica relativa a la concesión de dichas becas o ayudas, no es el de enseñanza, el cual es el que resulta específicamente contemplado en el art. $15 \mathrm{EAC}$, sino el de educación, título que, en su dimensión más profunda, ha de entenderse referido a las nociones de recibir educación o de ser educado.

(Conde Martín de Hijas): Se reitera el disentimiento que ya se explicitara en relación con la argumentación y fallo de la STC 188/2001. Se considera que la competencia del Estado tanto normativa como administrativo establecida en la Orden cuestionada tenía firme asidero constitucional en la materia enuncia en el art. 149.1.1 CE; se estima errónea al respecto la prevalencia conceptual del art. 149.1.30 CE respecto al art. 149.1.1 CE, por razón de una mayor especificidad de éste en relación al caso, con la consecuente limitación de las competencias del Estado, asentadas en tal específico título; y se estima asimismo errónea la equiparación de las becas a las subvenciones, a efectos de la aplicación al caso de la doctrina jurisprudencial sobre la territorialización de las últimas. 